\title{
ESTADO REGULADOR Y ALOJAMIENTO \\ COLABORATIVO. EL RÉGIMEN DE LA INTERVENCIÓN \\ PÚBLICA LIMITADORA DE LA PRESTACIÓN DEL \\ SERVICIO
}

\author{
JOANA M. SOCÍAS CAMACHO' \\ Universidad de las Islas Baleares \\ joana.socias@uib.es
}

Cómo citar/Citation

Socías Camacho, J. M. (2018).

Estado regulador y alojamiento colaborativo.

El régimen de la intervención pública limitadora de la prestación del servicio.

Revista de Administración Pública, 205, 131 -170.

doi: https://doi.org/10.18042/cepc/rap.205.04

\section{Resumen}

El alojamiento colaborativo, con sus impactos sobre el espacio y el medio ambiente urbano, por un lado, y sobre los principios de libertad de empresa, libre competencia y garantía de la unidad de mercado, por otro, constituye una actividad que no puede quedar al margen de la regulación. La salvaguarda de la ciudad como espacio de convivencia armónica y sostenible, desde el punto de vista social y ambiental, exige inevitablemente regímenes de intervención adecuados a la nueva realidad del fenómeno, cuya regulación no puede dejar de abordar cuestiones propias del urbanismo, la ordenación del territorio o la política de vivienda, como es la configuración de los barrios o las zonas donde se concentre la oferta —-mediante la zonificación-, la previsión de infraestructuras adecuadas o la oferta suficiente de alquiler o vivienda a precio razonable a la población residente. Junto a la perspectiva territorial, hay otra no menos importante que es la que afecta, por un lado, a los nuevos cauces intermediarios a través de los cuales se articula el alojamiento colaborativo, los marketplaces, y, por otro, al nuevo rol de los proveedores del servicio alojativo, los «peers» y los

1 Profesora titular de Derecho Administrativo. 
«professional services providers». Es la perspectiva de la actividad económica y de los derechos y libertades de los ciudadanos, cuya incidencia sobre la unidad de mercado es evidente.

\title{
Palabras clave
}

Estado regulador; alojamiento colaborativo; alquiler turístico; zonificación; libre competencia; unidad de mercado; intervención administrativa.

\begin{abstract}
Collaborative tourism, with its impacts on space and the urban environment, on the one hand, and on the principles of freedom of enterprise, free competition and guarantee of market unity, on the other, constitutes an activity that can not be left aside of regulation. The safeguarding of the city as a harmonious and sustainable coexistence space, from the social and environmental point of view, inevitably requires intervention regimes adapted to the new reality of the phenomenon, whose regulation can not fail to address issues specific to urban planning, the management of territory or housing policy, such as the configuration of neighborhoods or areas where the offer is concentrated -by means of zoning-, the provision of adequate infrastructures or the sufficient offer of rent or housing at a reasonable price to the resident population. Along with the territorial perspective, there is another, no less important one, which affects, on the one hand, the new intermediary channels through which the collaborative housing is articulated, the marketplaces, and, on the other, the new role of the providers of the accommodation service, the "peers" and the "professional services providers". It is the perspective of economic activity and the rights and freedoms of citizens, whose impact on market unity is evident.
\end{abstract}

\section{Keywords}

Regulatory State; collaborative accommodation; tourist rental; zoning; free competition; market unit; administrative intervention. 


\section{SUMARIO}

I. INTRODUCCIÓN. II. LOS PRIMEROS CAMBIOS REGULATORIOS: LA REFORMA DE LA LAU POR LA LEY 4/2013: 1. Objeto de la reforma. 2. La exclusión de la LAU se refiere a estancias de corta duración. III. LA REGULACIÓN DEL ALOJAMIENTO COLABORATIVO Y LA JUSTIFICACIÓN DE LA INTERVENCIÓN ADMINISTRATIVA LIMITADORA DE LA PRESTACIÓN DEL SERVICIO: 1. El principio de desarrollo territorial urbano y sostenible y la conexión entre urbanismo, vivienda y turismo. 2. Las restricciones al acceso a la comercialización turística en viviendas y su confrontación con la garantía de la unidad de mercado. Análisis de la Sentencia del Tribunal Constitucional, de 22 de junio de 2017: 2.1. La aplicación de la Directiva de servicios en la comercialización turística en viviendas. 2.2. El régimen de intervención administrativa en la actividad de comercialización turística en viviendas.

\section{INTRODUCCIÓN}

Los poderes públicos intervienen en el desarrollo de las actividades económicas a través de la regulación, con el objetivo de defender los intereses generales. Esta intervención pública debe valorar de una forma equilibrada y ponderada todas las vertientes implicadas en el ejercicio de la concreta actividad y ha de limitarse a aquello que sea estrictamente necesario para el cumplimiento del interés general. El auge de la llamada economía colaborativa ha modificado claramente la configuración de dos sectores muy importantes, el transporte (con la aparición de Uber o Cabify) y el turismo (con la irrupción del alojamiento colaborativo $)^{3}$, dotándoles de unos perfiles y características completamente distintos de los que veníamos conociendo hasta ahora, y que

2 Véase el recomendable trabajo de G. Doménech Pascual (2015), «La regulación de la economía colaborativa (El caso "Uber contra el taxi")», Revista CEFLEGAL, CEF, 175-176, págs. 61-104.

3 Es de gran interés el trabajo que sobre el alojamiento colaborativo ha publicado A. M. de la Encarnación (2016), «El alojamiento colaborativo: viviendas de uso turístico y plataformas virtuales», Revista de Estudios de la Administración Local y Autonómica, nueva época, 5. 
merecen atención por parte de los poderes públicos de cara a actualizar su regulación.

El turismo colaborativo, con sus impactos sobre el espacio y el medio ambiente urbano, por un lado, y sobre los principios de libertad de empresa, libre competencia y garantía de la unidad de mercado, por otro, constituye sin lugar a dudas una actividad económica que no puede quedar al margen de la regulación. Una de las innovaciones destacadas del fenómeno del alojamiento colaborativo - entendido como un nuevo modelo de negocio lejos de lo que empezó siendo una transacción entre iguales para compartir la vivienda o home sharing, como ha subrayado De la Encarnación (2016) — es la que afecta a la proyección territorial de dicha actividad económica. Si hasta ahora el turismo se había configurado como un sector espacialmente acotado, restringido a las llamadas "zonas turísticas», y urbanísticamente delimitado, vinculado a determinadas tipologías edificatorias (básicamente hoteles y apartamentos), hoy en día es evidente que la oferta y la demanda turística han rebasado con mucho esos márgenes, penetrando en el tejido de las ciudades y confundiéndose con las tipologías habitacionales propias del espacio urbano (residencia unifamiliar y plurifamiliar). Todo ello ha generado unos impactos negativos ciertamente notables sobre el entorno urbano y en la política de vivienda.

Junto a la perspectiva territorial de la nueva modalidad turística alojativa, hay otra no menos importante que es la que afecta, por un lado, a los nuevos cauces intermediarios - aún muy difusos y poco o nada regulados - a través de los cuales se articula el alojamiento colaborativo, las plataformas o marketplaces (como Airbnb o Homeaway), y, por otro, al nuevo rol de los proveedores del servicio alojativo, los "peers» y los "professional services providers» ${ }^{4}$ y a la configuración de los derechos de propiedad, libertad de empresa o libre competencia de estos proveedores. Es la perspectiva de la actividad económica y de los derechos y libertades de los ciudadanos, cuya incidencia sobre la unidad de mercado es evidente.

Los cambios regulatorios en el sector del alquiler de viviendas con fines turísticos, dados fundamentalmente por la reforma de la Ley 29/1994, de 24

4 Según la Comunicación de la Comisión Europea sobre la agenda europea para la economía colaborativa, COM (2016) 356 final, de 2 de junio de 2016, la economía colaborativa estaría compuesta por tres tipos de agentes, en función de su papel: a) proveedores de servicios, que a su vez pueden ser de dos tipos: i) particulares, que prestan sus servicios de forma ocasional (peers) y ii) profesionales, que actúan dentro del ámbito propio de su actividad (professional services providers); b) usuarios de los servicios; c) intermediarios, que conectan a través de una plataforma online, a los proveedores con los usuarios. 
de noviembre, de arrendamientos urbanos (en adelante, LAU) llevada a cabo por la Ley 4/2013, de 4 de junio, de medidas de flexibilización y fomento del mercado del alquiler de viviendas (en adelante, Ley 4/2013), han impulsado que algunas comunidades autónomas, con base en sus competencias turísticas, hayan regulado el régimen jurídico del alquiler turístico de viviendas. Es el caso de Aragón (2015), Canarias (2015), Cataluña (2012), la Comunidad de Madrid (2014), Andalucía (2016), Galicia (2017) o Islas Baleares (2017)5, por destacar algunos. En determinados lugares (Barcelona, Madrid o Islas Baleares, especialmente Ibiza) desde el verano de 2016, el alquiler turístico ha tenido un incremento espectacular que incluso ha provocado en la ciudadanía alarma social y sensación de saturación turística, debido al uso indiscriminado y absolutamente desproporcionado de dicha figura. Concretamente, el alquiler turístico en edificios plurifamiliares en régimen de propiedad horizontal se ha intensificado exponencialmente, tanto a nivel particular (el proveedor del servicio alquila su propiedad de forma ocasional, peers) como sobre todo a nivel profesional (el proveedor del servicio explota la vivienda de forma habitual, professional services providers); y ello incluso con frecuencia al margen de los cauces legales y reglamentarios, que a veces ni siquiera existen ${ }^{6}$.

5 Sobre las nuevas regulaciones en España acerca del alquiler turístico, véase N. A. Guillén Navarro (2015), «La vivienda de uso turístico y su incidencia en el panorama normativo español», Revista Aragonesa de Administración Pública, 45-46, págs. 101144. Destaca la siguiente normativa: Aragón (Decreto 80/2015, de 5 de mayo del Gobierno de Aragón, por el que se aprueba el Reglamento de las viviendas de uso turístico en Aragón), Canarias (Decreto 113/2015, de 22 de mayo, por el que se aprueba el Reglamento de las viviendas vacacionales de la Comunidad Autónoma de Canarias), Cataluña (Decreto 159/2012, de 20 de noviembre, de establecimientos de alojamiento turístico y de viviendas de uso turístico), Comunidad de Madrid (Decreto 79/2014, de 10 de julio, del Consejo de Gobierno, por el que se regulan los apartamentos turísticos y las viviendas de uso turístico de la Comunidad de Madrid), Andalucía (Decreto 28/2016, de 2 de febrero, de las viviendas con fines turísticos y de modificación del Decreto 194/2010, de 20 de abril, de establecimientos de apartamentos turísticos), Galicia (Decreto 12/2017, de 26 de enero, que regula la ordenación de apartamentos turísticos, viviendas turísticas y viviendas de uso turístico), o Islas Baleares (Ley 6/2017, de 31 de julio, de modificación de la Ley 8/2012, de 19 de julio de turismo de las Islas Baleares, relativa a la comercialización de estancias turísticas en viviendas).

6 Como es el caso de la Ley 8/2012, de 19 de julio, de Turismo de las Islas Baleares (antes de su modificación mediante la Ley 6/2017, de 31 de julio, de modificación de la Ley 8/2012, de 19 de julio de turismo de las Islas Baleares, relativa a la comercialización de estancias turísticas en viviendas), que prohibía de forma expresa el alquiler turístico en edificios plurifamiliares. 
Encajar en el ordenamiento jurídico español la regulación de la comercialización turística de las viviendas, sobre todo de aquellas que están sometidas al régimen de propiedad horizontal, así como su incidencia en el entorno urbano, es todo un reto para el derecho administrativo actual, que tiene que enfrentarse a lo que hoy se conoce como economía colaborativa, y más concretamente, alojamiento colaborativo. La nueva regulación no puede obviar las diversas problemáticas que el alquiler turístico puede comportar, que son múltiples y variadas, y que abarcan desde la salvaguarda del derecho al domicilio libre de inmisiones, el urbanismo, la ordenación del territorio, el medio ambiente adecuado y el derecho a la vivienda digna hasta el derecho de propiedad, el derecho de libertad de empresa o la unidad de mercado. El nuevo modelo de la mejora regulatoria (o desregulación), importado de la normativa comunitaria y la integración europea (Muñoz Machado, Vaquer Caballería, Embid Irujo, Esteve Pardo) ${ }^{7}$ altera la concepción de la posición que ha de asumir el Estado en relación con la sociedad, según ha destacado Muñoz Machado $(2011)^{8}$, que teoriza sobre el paso del Estado gestor al Estado regulador y garante. El derecho comunitario ha afectado notablemente el derecho administrativo en la regulación de las actividades de los particulares y, en concreto, de los emprendedores de negocio, ya que se instaura la libertad de establecimiento, la libre competencia y la unidad de mercado. Sin embargo, dichos derechos y principios han de convivir con otros como la protección del medio ambiente y del entorno urbano o el derecho a la vivienda digna, de modo que habrá de compatibilizar unos con otros.

7 Véase S. Muñoz Machado (20 I I), Tratado de Derecho Administrativo y Derecho Público General, IV, Madrid: Iustel (págs. 487-49o); M. Vaquer Caballería (20 I I), «El criterio de la eficiencia en el Derecho Administrativo», Revista de Administración Pública, 186, págs. 91-135 (pág. 124). Además, véase también A. Embid Irujo (201 2), «El derecho público de la crisis económica», en A. Blasco Esteve (coord.), El derecho público de la crisis económica. Transparencia y sector público. Hacia un nuevo Derecho Administrativo, Actas del VI Congreso de la Asociación Española de Derecho Administrativo (págs. 21-121), Madrid: Instituto Nacional de Administración Pública (pág. 112); y J. Esteve Pardo (20I4), «Perspectiva e impacto de la crisis desde la nueva correlación entre Estado y sociedad», Documentación Administrativa, 1,16 págs.

8 Como dice Muñoz Machado (20 I I: 490), «no es lo mismo un Estado que se abstiene y retrae, potenciando al máximo la posibilidad de que la sociedad asuma la satisfacción de sus necesidades y organizando los mercados de un modo que los intereses privados y los públicos se conjuguen ordenadamente en ellos, que un Estado que, como el del siglo XX, se preocupa de participar activamente como gestor de empresas y prestador de servicios de toda clase». 
La proliferación del número de viviendas que en los últimos años se comercializan turísticamente ha provocado una enorme presión sobre las ciudades y el territorio, manifestada de diversas formas: saturación del espacio urbano, restricciones de acceso al mercado inmobiliario, deterioro del medio ambiente urbano, incremento de las necesidades de dotaciones, infraestructuras y servicios, por citar algunas. Frente a esta situación, la salvaguarda de la ciudad como espacio de convivencia armónica y sostenible, desde el punto de vista social y ambiental, exige inevitablemente regímenes de intervención adecuados a la nueva realidad del fenómeno. La regulación de este nuevo tipo de alojamiento turístico — que ha superado ampliamente los márgenes del modelo turístico del siglo pasado - no puede dejar de abordar cuestiones propias del urbanismo, la ordenación del territorio o la política de vivienda, como es la configuración de los barrios o las zonas donde se concentre la oferta —-mediante el uso de técnicas clásicas como la zonificación—, la previsión de infraestructuras adecuadas o la oferta suficiente de alquiler o vivienda a precio razonable a la población residente ${ }^{9}$. Los instrumentos propios de la función urbanística y sus técnicas clásicas de ordenación de las ciudades habrán de utilizarse junto con otras más modernas, como, por ejemplo, las referidas a las dotaciones de los servicios domésticos o el establecimiento de cupos o techo de plazas; es decir, esos instrumentos o técnicas clásicas del urbanismo no pueden funcionar de manera aislada, sino que se han de combinar con los propios de otras vertientes de la intervención administrativa, como son en particular los que se refieren a la política de vivienda o a la intervención general sobre la actividad económica. Así, el urbanismo y la política de vivienda no pueden quedar indiferentes ante la irrupción del alojamiento colaborativo, con el fin de asegurar una racional ordenación del espacio urbano, que garantice la adecuada convivencia entre turistas y residentes y minimice los impactos ambientales, y con el objetivo de amparar el derecho de acceso a la vivienda digna.

Sin embargo, a nadie se le escapa que esas vertientes de intervención, si bien son necesarias, son insuficientes si no se tiene en cuenta la nueva situación de los "peers» y los «professional services providers» y su incidencia sobre los poderes públicos y la Administración. Los poderes públicos están obligados a adoptar un rol distinto frente al impulso auspiciado por el derecho comunitario de la capacidad de emprendimento de la sociedad, rol que tiene

9 Sobre las relaciones entre urbanismo y vivienda, véase J. Ponce Solé (2017), "Cincuenta ańos de relaciones entre derecho urbanístico y vivienda asequible en España", Revista de Derecho urbanístico y Medio Ambiente, 311, págs. 343-372; y del mismo autor junto a J. M. Moltó Darner (2017), Derecho a la vivienda y función social de la propiedad. Nuevas politicas públicas en el marco del servicio público de alojamiento, Navarra: Thomson Reuters Aranzadi. 
que incorporarse en la regulación y definición del nuevo turismo colaborativo. La aparición de nuevos cauces de oferta-demanda a través de los cuales se materializa el alojamiento colaborativo (los marketplaces) comporta un cambio en el modo de plantear las relaciones entre el poder público, los ciudadanos (propietarios y empresarios proveedores de servicios), las nuevas plataformas intermediarias o «marketplaces» y los consumidores (usuarios), que no se puede reducir a la clásica intervención de policía administrativa, sino que exige nuevas fórmulas y espacios de colaboración público-privada propios del Estado regulador. En la era regulatoria y de la economía colaborativa, las técnicas clásicas de intervención administrativa han de ajustarse en el marco de la unidad de mercado, de la libre competencia y de la Directiva europea de servicios.

Hecha esta introducción, y antes de pasar a analizar con detalle todas las cuestiones que acaban de apuntarse, conviene, sin embargo, con carácter previo, poner los ojos en la regulación que contiene la legislación estatal sobre arrendamientos urbanos del alquiler turístico, fudamentalmente debido al solapamiento de esta figura con otra muy importante, la del arrendamiento de temporada de la LAU, y la consiguiente situación de confusión jurídica que ello ha provocado.

\section{LOS PRIMEROS CAMBIOS REGULATORIOS: LA REFORMA DE LA LAU POR LA LEY 4/2013}

\section{OBJETO DE LA REFORMA}

La LAU, como ya se ha advertido, fue modificada mediante la Ley 4/2013 con un objeto claro: excluir el alquiler de viviendas para un uso turístico de la regulación contenida en la propia LAU. Tras la reforma de la LAU de 2013, se excluyó expresamente del ámbito de aplicación de dicha ley el arrendamiento temporal de viviendas para uso turístico, al introducir un nuevo apartado al artículo correspondiente a los arrendamientos excluidos [el apartado e) del art. 5], referido a la "la cesión temporal de uso de la totalidad de una vivienda amueblada y equipada en condiciones de uso inmediato, comercializada o promocionada en canales de oferta turística y realizada con finalidad lucrativa, cuando esté sometida a un régimen específico, derivado de su normativa sectorial».

La reforma introducida en el artículo 5.e) de la LAU ha planteado numerosos problemas sobre los arrendamientos de viviendas para uso turístico de corta duración, sobre todo en edificios plurifamiliares. El cumplimiento y la verificación de los requisitos exigidos por el art. 5.e) de la LAU, sobre todo del que hace referencia a que la cesión fuera comercializada o promocionada 
en canales de oferta turística, se han demostrado de gran complejidad en la práctica, dada la proliferación de portales de internet o marketplaces que ofrecen el alquiler de viviendas. Pero, además, la problemática de la regulación que establece el citado art. 5.e) deriva también de su solapamiento con la figura de los arrendamientos de temporada previstos en el art. 3.2 de la misma ley. Ello es así porque un mismo arrendamiento de vivienda y con finalidad vacacional puede ser considerado o bien arrendamiento de temporada o bien arrendamiento turístico. Efectivamente, lo que pretendía el legislador estatal era delimitar dos situaciones distintas para someterlas a regímenes jurídicos diferentes: a) una, referida a los arrendamientos de fincas urbanas celebrados por temporada (conocido como arrendamiento por temporada vacacional), prevista en el apdo. 2 del art. 3 de la LAU, titulado "Arrendamiento para uso distinto del de vivienda" y sometida al régimen jurídico civil (apdo. 3 del art. 4 de la LAU); a título de ejemplo, sería el caso del tradicional alquiler de una vivienda entre dos particulares y en la que no se prestan servicios complementarios (limpieza, reposición de sábanas, mantenimiento de servicios, servicio de atención al público), sino solo los servicios básicos de electricidad o de recogida de basuras, es decir, los servicios propios de los arrendamientos urbanos. b) Y otra, relativa al arrendamiento de viviendas con prestación de servicios complementarios, que se comercializan mediante canales de oferta turística y que están sometidas a un régimen específico turístico, prevista en el apdo. e) del art. 5 de la LAU, titulado "Arrendamientos excluidos»; por ejemplo, sería el caso del alquiler de una vivienda mediante una agencia o una plataforma turística y en la que se prestan servicios complementarios de hospedaje, como limpieza, recepción, ropa de cama, mantenimiento, asistencia, etc., propios de los establecimientos hoteleros (están excluidos de la LAU). Como ha advertido Botello Hermosa ${ }^{10}$, coexisten dos figuras muy parecidas que se solapan pero que, sin embargo, no son la misma, al estar sujetas a regímenes distintos en función de si el arrendamiento se realiza de manera ocasional sin ordenar medios ni recursos, esto es, sin haber creado una organización que preste servicios complementarios sino limitándose el propietario a la prestación de los servicios básicos (electricidad, basura), como es el caso del alquiler de temporada sometido a la legislación estatal contenida en la LAU; o de si, por el contrario, el arrendamiento se realiza con habitualidad, profesionalidad y con complemento de estructura y de servicios, ofreciendo algunos beneficios complementarios propios de establecimientos

10 J. M. Botello Hermosa (2016), «Los arrendamientos por temporada en la Ley 29/1994, de 24 de noviembre, de arrendamientos urbanos", Revista Critica de Derecho Inmobiliario, 756, págs. 1959-1990. 
hoteleros - típicos servicios de los contratos de hospedaje-, en cuyo caso se trata del alquiler turístico excluido de la LAU, y que está sometido, siempre que exista, al régimen previsto en la normativa sectorial sobre turismo de las comunidades autónomas ${ }^{11}$.

\section{LA EXCLUSIÓN DE LA LAU SE REFIERE A ESTANCIAS DE CORTA DURACIÓN}

Tras la reforma de la LAU de 2013, las comunidades autónomas han empezado a aprobar normativas que regulan el alquiler turístico que han de cumplir con las premisas establecidas en la LAU: a) cesión temporal de uso; b) totalidad de una vivienda amueblada y equipada; c) posibilidad de utilización de forma inmediata; c) comercialización y publicidad en canales de oferta turística; d) fin lucrativo. A partir de esta previsión, según ha señalado Guillén Navarro (2015), la vivienda de uso turístico se ha definido como «aquella que amueblada o equipada para ser utilizada de inmediato, es cedida de modo temporal, habitual y lucrativo por su propietario o propietarios a terceros a través de una previa comercialización o promoción mediante canales de oferta turística». De esta definición, que ha sido seguida en mayor o menor medida por las diversas normativas autonómicas aprobadas, se destacan los aspectos de la temporalidad, la habitualidad, los canales de oferta turística y la finalidad lucrativa ${ }^{12}$.

11 Al respecto, véase M. A. Martos Calabrús (2014), «El contrato de arrendamiento de vivienda vacacional tras la reforma del artículo 5 de la LAU por la Ley 4/2013", Revista de Derecho Civil, vol. 1, 1, págs. 91-102 (págs. 91-95).

12 Así, por ejemplo, en Cataluña, el artículo 66 del Decreto 159/2012, de 20 de noviembre, de establecimientos de alojamiento turístico y de viviendas de uso turístico, establece que «tienen la consideración de viviendas de uso turístico aquellas que son cedidas por su propietario, directamente o indirectamente, a terceros, de forma reiterada y a cambio de contraprestación económica, para una estancia de temporada, en condiciones de inmediata disponibilidad y con las características establecidas en ese Decreto». En Aragón, el art. 2 del Decreto 80/2015, de 5 de mayo, por el que aprueba el Reglamento de las viviendas de uso turístico, define las viviendas de uso turístico como «aquellos inmuebles sometidos al régimen de propiedad horizontal, viviendas unifamiliares aisladas u otras pertenecientes a complejos inmobiliarios privados que son cedidas de modo temporal por sus propietarios, directa o indirectamente, a terceros para su alojamiento turístico, amuebladas y equipadas en condiciones de uso inmediato, comercializadas o promocionadas en canales de oferta turística y con una finalidad lucrativa». En Castilla y León, el art. 4 del Decreto 3/2017, de 16 de febrero, por el que se regulan los establecimientos de alojamiento en la modalidad de vivienda 
Interesa ahora detenerse en un aspecto muy importante, el de la temporalidad, para ver cómo este afecta a la figura del arrendamiento de temporada de la LAU y a su distinción con el alquiler turístico. La nota característica en el arrendamiento por temporada de la LAU no es la duración del contrato, sino la motivación que lleva a contratar, es decir, la causa (fundamentalmente por temporada académica, vacacional o de segunda residencia), con el fin de proporcionar un alojamiento transitorio por un tiempo determinado - que libremente pactan las partes- ${ }^{13}$, cuya duración parece que se está refiriendo a un periodo largo de ocupación, por la exigencia de dos meses de fianza ${ }^{14}$.

de uso turístico, entiende que son empresas de alojamiento en dicha modalidad «tanto persona física como jurídica, propietaria o no de la vivienda de uso turístico, que presta a los turistas, de forma habitual y con ánimo de lucro, el servicio de alojamiento en la modalidad de vivienda de uso turístico». En Galicia, el art. 5 del Decreto 12/2017, de 26 de enero, por el que se establece la ordenación de apartamentos turísticos, viviendas turísticas y viviendas de uso turístico, define las viviendas de uso turístico como «las cedidas a terceras personas, de manera reiterada y a cambio de contraprestación económica, para una estancia de corta duración, amuebladas y equipadas en condiciones de inmediata disponibilidad y con las características previstas en este decreto [...]». Y en Andalucía, el art. 3 del Decreto 28/2016, de 2 de febrero, de las viviendas con fines turísticos y de modificación del Decreto 194/2010, de 20 de abril, de establecimientos de apartamentos turísticos, establece que las viviendas con fines turísticos son «aquellas ubicadas en inmuebles situados en suelo de uso residencial, donde se vaya a ofrecer mediante precio el servicio de alojamiento en el ámbito de la Comunidad Autónoma de Andalucía, de forma habitual y con fines turísticos».

13 La Sentencia de la Audiencia Provincial de Barcelona de 1 de junio de 2004 establece al respecto: «Reiteradas sentencias del Tribunal Supremo han establecido, con criterio uniforme seguido de forma constante por la jurisprudencia de las Audiencias Provinciales, que la calificación de arrendamiento de temporada no deriva del plazo concertado sino de la finalidad de la ocupación, ajena a la ocupación como residencia habitual del arrendatario, siendo ocasional y esporádica; de manera que el arrendamiento se hace en atención, no a la necesidad del arrendatario de establecer su vivienda, sino para ocuparla de una forma accidental y en épocas determinadas por razón de circunstancias distintas de la instalación de la residencia permanente y domicilio habitual». El Tribunal Supremo, en la Sentencia de 15 de diciembre de 1999, expuso que «la nota esencial del arrendamiento de temporada es la de haberse convenido el uso durante un plazo concertado para habitar transitoriamente y por razones diversas de modo que la ocupación responde a exigencias circunstanciales, esporádicas o accidentales determinantes del contrato y elevadas expresamente a la condición de causa por las partes y no a la necesidad de habitar como residencia habitual y permanente». Debe prestarse especial atención al tema de la fianza (art. 36 LAU), por tratarse de una previsión de obligado cumplimiento en el arrendamiento de temporada. Dicho 
La exclusión de la LAU va referida a los arrendamientos que implican una «cesión de uso temporal», pero en ningún momento la Ley concreta dicha temporalidad. Es decir, la LAU no detalla si el arrendamiento que excluye ha de ser aquel que se establece por periodos de larga duración o el que se refiere a estancias de corta duración; concreción que, además cabe recordar, tampoco realiza la LAU en la regulación del arrendamiento por temporada, porque la causa que justifica este tipo de arrendamiento no es la duración de la estancia sino el motivo por el cual se contrata.

Aquí está la clave que provoca la confusión en la delimitación entre el arrendamiento de temporada y el alquiler turístico, confusión que a la postre ha generado situaciones de intrusismo y competencia desleal debido al aumento descomunal del uso del alquiler turístico impulsado por los diferentes canales de oferta turística (desde agencias de viajes o centrales de reservas hasta otras empresas de mediación y organización de servicios turísticos, incluidos los canales de intermediación virtuales, así como la difusión por Internet, u otros medios de información, difusión y comunicación) ${ }^{15}$. A título informativo, son elocuentes los datos del número de usuarios que utilizaron una conocida plataforma virtual (Airbnb) en su visita a España en 2016, que creció un $82 \%$ en comparación con 2015 , alcanzando los 5,4 millones, una cifra mayor que la suma de los seis años anteriores. Así, desde desde la creación de Airbnb en 2008, cerca de 11 millones de personas se han alojado en viviendas anunciadas en esta plataforma en España, donde actualmente hay 187000

artículo establece la obligatoriedad de una fianza de dos mensualidades; y, además, la disposición adicional tercera de la LAU señala que las comunidades autónomas podrán establecer la obligación de que los arrendadores de finca urbana depositen el importe de la fianza, sin devengo de interés, a disposición de la Administración autonómica o del ente público que se designe hasta la extinción del correspondiente contrato. La LAU es muy clara en lo relativo a la fianza de dos mensualidades y a la posibilidad del depósito de la misma en un registro de la comunidad autónoma, si así se determina. Al exigirse en estos casos una fianza tan elevada (resaltar que para el alquiler de vivienda solo se exige una mensualidad), parece que con esta medida se está aludiendo a arrendamientos por temporada a largo plazo, ya sea por motivos vacacionales, de segunda residencia o por temporada académica. Para evitar el fraude de ley que supondría decir que se trata de un alquiler de «segunda residencia» (por tanto, sometido a la LAU) cuando en realidad es "por vacaciones», reviste importancia la exigencia de la fianza de dos meses y su depósito en un registro para los arrendamientos de temporada de larga duración, cuya implantación podría facilitar y hacer más efectivo el control de los alquileres y de su posible fraude.

15 Esto es lo que entiende por canales de oferta turística el artículo 4.b) del Decreto 80/2015 de Castilla y León. 
anuncios, siendo su estancia media de 4,3 noches. Del estudio de las distintas normativas aprobadas hasta ahora por las comunidades autónomas sobre la figura del alquiler turístico se desprende, sin embargo, con claridad y sin titubeo, que dicha figura está pensada, en efecto, para estancias de corta duración; en los casos analizados, las previsiones normativas de los periodos de tiempo de la estancia oscilan entre duraciones máximas de un mes o de dos meses. Se trata, incluso, de periodos máximos de tiempo que, como vemos, superan con creces las 4,3 noches de media de los usuarios del alquiler turístico a las que hacíamos referencia ${ }^{16}$.

16 En Cataluña, por ejemplo, el apdo. 3 del art. 66 del Decreto 159/2012 «considera estancia de temporada toda ocupación de la vivienda por un periodo de tiempo continuo igual o inferior a 31 días». Aragón contiene una regulación más detallada. Así, el apdo. c) del art. 2 del Decreto 80/2015 entiende por «cesión temporal: toda ocupación de la vivienda por un periodo de tiempo continuo igual o inferior a un mes por usuario»; en el apdo. 2 del art. 4 se excluye del ámbito de aplicación de dicho decreto «los arrendamientos de fincas urbanas contemplados en la Ley 29/1994, de 24 de noviembre, de Arrendamientos Urbanos, o normativa que la sustituya»; y en el apdo. 3 del propio artículo se establece la presunción normativa de que «la cesión de uso de una vivienda se encuentra sujeta a este Reglamento cuando su promoción o comercialización se efectúe a través de canales de oferta turística, o cuando se ceda por un período igual o inferior a un mes por usuario». Castilla y León, en una línea parecida a la de Aragón, establece en el apdo. b) del art. 2.2 del Decreto 3/2017 que se excluye del ámbito de aplicación de dicho decreto «los arrendamientos de fincas urbanas que se destinen a vivienda, para residencia permanente, tal y como aparecen definidos en la normativa sobre arrendamientos urbanos, el subarriendo parcial de vivienda, el derecho de habitación, y el arrendamiento para usos distintos del de vivienda»; y el apdo. d) del art. 4 concreta la temporalidad — en este caso de dos meses - cuando se define el servicio de alojamiento en la modalidad de vivienda de uso turístico como «la prestación de hospedaje de forma habitual y con carácter temporal, esto es por un plazo máximo de dos meses seguidos a un mismo turista». Galicia, como se ha visto antes, es la primera comunidad autónoma que manifiesta expresamente que se trata de «estancias de corta duración» (apdo. 1 del art. 5 del Decreto 12/2017), señalándose luego que «constituyen estancias de corta duración aquellas en las que la cesión de uso es inferior a treinta días consecutivos, quedando fuera del ámbito de aplicación las que sobrepasen esa duración» (apdo. 2). Y Andalucía opta por los dos meses de estancia como máximo; así, el apdo. b) del art. 1.2 del Decreto 28/2016 excluye de su ámbito de aplicación «las viviendas contratadas por tiempo superior a dos meses computados de forma continuada por una misma persona usuaria». 


\section{LA REGULACIÓN DEL ALOJAMIENTO COLABORATIVO Y LA JUSTIFICACIÓN DE LA INTERVENCIÓN ADMINISTRATIVA LIMITADORA DE LA PRESTACIÓN DEL SERVICIO}

\section{EL PRINCIPIO DE DESARROLLO TERRITORIAL URBANO Y SOSTENIBLE $Y$ LA CONEXIÓN ENTRE URBANISMO, VIVIENDA Y TURISMO}

Los cambios normativos dados por la reforma de la LAU mediante la Ley 4/2013 son los que fundamentalmente han impulsado que una docena de comunidades autónomas hayan regulado el régimen jurídico del alquiler turístico de viviendas. Sin embargo, pese al establecimiento de requisitos por la legislación de arrendamientos urbanos y pese también a la nueva regulación autonómica aprobada con posterioridad, lo cierto es que la proliferación del número de viviendas que en los últimos años se comercializan turísticamente en formato de estancia corta a través de marketplaces (por tanto, no sometidas a la LAU, pero sí a la normativa autonómica turística) no se ha podido controlar, y ello ha provocado una enorme presión sobre las ciudades y el territorio, manifestada de diversas formas: saturación del espacio urbano, restricciones de acceso al mercado inmobiliario, deterioro del medio ambiente urbano e incremento de las necesidades de dotaciones, infraestructuras y servicios. Como ya se dijo más arriba, la regulación de este nuevo tipo de alojamiento turístico no puede dejar de abordar cuestiones propias del urbanismo, la ordenación del territorio o la política de vivienda; de modo que aspectos como la configuración de las zonas donde se concentre la oferta, la previsión de infraestructuras adecuadas o la oferta suficiente de alquiler o vivienda a precio razonable a la población residente son segmentos que no pueden quedar al margen de la regulación del alojamiento colaborativo, con el fin de asegurar una racional ordenación del espacio urbano, que garantice la adecuada convivencia entre turistas y residentes y minimice los impactos ambientales, y con el objetivo de armonizar el derecho a la vivienda digna con el derecho a la explotación económica de la vivienda.

Algunas normativas, como, por ejemplo, el Plan Especial Urbanístico de Alojamientos Turísticos del Ayuntamiento de Barcelona (aprobado el 27 de enero de 2017, BOPB de 7 de marzo de 2017) o la Ley 6/2017, de 31 de julio, de modificación de la Ley 8/2012, de 19 de julio de turismo de las Islas Baleares, relativa a la comercialización de estancias turísticas en viviendas, ponen énfasis en el principio de desarrollo territorial urbano y sostenible y la conexión entre urbanismo, vivienda y turismo ${ }^{17}$; concretamente, en la necesidad

17 El art. 75.1 de la Ley Ley 8/2012, de 19 de julio de turismo de las Islas Baleares, relativa a la comercialización de estancias turísticas en viviendas, en la redacción dada 
de que los instrumentos de planificación territorial y urbanística controlen la delimitación de las zonas aptas para la comercialización turística. Es decir, se establece que los instrumentos propios de la función urbanística y sus técnicas clásicas de ordenación de las ciudades (como la zonificación) sean utilizados en la ordenación del espacio urbano ante la irrupción del alojamiento colaborativo. Pero se va más allá, y junto a dichos instrumentos clásicos se invocan otros instrumentos propios de otras vertientes de la intervención administrativa que se refieren a la política de vivienda o a la intervención general sobre la actividad económica, como es el establecimiento de un techo de plazas ${ }^{18}$, la exigencia de dotaciones de los servicios domésticos (contadores individuales de agua y otros suministros), el preceptivo acuerdo de la junta de propietarios en viviendas en régimen de propiedad horizontal para poder comercializar el alquiler turístico, la prohibición de ofrecer el alquiler turístico en viviendas de menos de cinco años de antigüedad o el veto a formalizar contratos para comercializar habitaciones para este tipo de estancias ${ }^{19}$.

Todas estas medidas suponen, en mayor o menor grado, una restricción al acceso a la comercialización turística en viviendas, y pueden implicar una confrontación con el principio de libertad de empresa, el derecho de propiedad, las leyes de la competencia y la garantía de la unidad de mercado, como así se ha subrayado por parte de las Autoridades de la Competencia

por la modificación de este precepto llevada a cabo por el Decreto Ley 3/2017, de 4 de agosto, establece lo siguiente: «La ordenación territorial de los recursos turísticos de cada una de las Islas se tiene que hacer de conformidad con lo que dispone esta Ley, de acuerdo con las normas de ordenación del territorio y de vivienda, y los instrumentos de planeamiento aplicables».

18 Una de las novedades que lleva a cabo la Ley 6/2017, de 31 de julio, de modificación de la Ley 8/2012, de 19 de julio de turismo de las Islas Baleares, relativa a la comercialización de estancias turísticas en viviendas, tiene que ver con la fijación de un techo de plazas en la comercialización turística en viviendas de uso residencial. Dada la enorme presión sobre el territorio, las carreteras, las infraestructuras, el medio ambiente y los recursos disponibles, la Ley prevé, como dice la exposición de motivos, «que se mantenga de manera real un techo o límite máximo de plazas turísticas, que debe venir determinado por las legalmente existentes más las integradas en las bolsas de plazas turísticas de que dispongan las Administraciones turísticas. Este techo, en todo caso, podrá ser modificado por los planes territoriales insulares (PTI) y, en su caso, por los planes de intervención en ámbitos turísticos (PIAT)»; y ello en base a razones medioambientales y de ordenación del territorio, en la línea señalada por la Organización Mundial del Turismo (OMT).

19 Todas estas restricciones están previstas en la Ley 6/2017, de 31 de julio, de modificación de la Ley 8/2012, de 19 de julio de turismo de las Islas Baleares, relativa a la comercialización de estancias turísticas en viviendas. 
y del propio Ministerio de Economía y Competitividad, que en varios de sus informes ${ }^{20}$ afirman que limitaciones semejantes contienen restricciones no justificadas, poco proporcionadas, contrarias a la Directiva de servicios y a las leyes de transposición, razón por la que apuestan por la desregulación y la autorregulación, como muy bien ha destacado Rodríguez Font $(2017)^{21}$.

Sin embargo, no puede obviarse que estas medidas restrictivas tienen su fundamento, en gran proporción, en los principios constitucionales en materia de suelo y medio ambiente, concretamente, en el principio de desarrollo territorial urbano y sostenible. La Carta Magna conecta la calidad de vida con la tutela ambiental y el racional uso de los recursos naturales, en el marco del vínculo entre economía y protección ambiental, y con los ojos puestos en un desarrollo económico equilibrado. Esto lleva a la necesidad de compaginar, en la forma que en cada caso decida el legislador competente, la protección de ambos bienes constitucionales: el medio ambiente y el desarrollo económico, tal como ha venido reconociendo tanto el Tribunal Constitucional como el Tribunal Supremo ${ }^{22}$. El desarrollo sostenible y la concreta búsqueda del valor

20 Véase, de la Comisión Nacional de los Mercados y Valores (CNMV), Estudio sobre los nuevos modelos de prestación de servicios y la economía colaborativa, de marzo de 2016 (resultados preliminares E/CNMV/004/15); Informe económico sobre el Decreto 113/2015, de 22 de mayo, por el que se aprueba el Reglamento de las viviendas vacacionales de la Comunidad de Canarias - CNMV LA/03/15-. De la Autoridad Catalana de la Competencia (ACCO): Nota sobre la aprobación inicial del Plan Especial Urbanistico de Alojamientos Turisticos (PEUAT) de Barcelona, ref. OB 26/2016; Transacción entre iguales (p2p). Un paso adelante, mayo de 2016, ref. ES 10/2015. Y véase del Ministerio de Economía y Competitividad, Informe sobre el proyecto de modificación de la Ley 8/2012, de 19 de julio, de turismo de las Islas Baleares, relativa a la comercialización de estancias turísticas en viviendas, de 24 de mayo de 2017.

$21 \mathrm{Al}$ respecto, son muy interesantes los trabajos de M. Rodríguez Font (2017), «Barreras regulatorias a la economía colaborativa y nuevas vías de impugnación de normas: el caso de las viviendas de uso turístico", Revista Española de Derecho Administrativo, 182, págs. 409-444 (págs. 427-431), y «La regulació de l'allotjament col.laboratiu a Catalunya: análisis de les propostes de l'autoritat de la competència», Revista Catalana de Dret Públic, 53, págs. 163-181 (págs. 168-180).

22 El derecho a la libertad de empresa recogido en el art. 38 de la Constitución no es un derecho con un contenido absoluto y tampoco es sinónimo de «economía de libre empresa», sino que, como ha señalado el Tribunal Supremo, va referido a un sistema económico en el que la libertad empresarial es un factor importante, pero no el único, de suerte que la libertad de empresa aparece siempre matizada por exigencias de la economía general. El Tribunal Constitucional en numerosas sentencias tiene declarado en este sentido que el propio art. 38 de la Constitución limita la libertad de empresa con las exigencias de la economía general y de la planificación, limitación 
superior «calidad de vida» comprende así la función principal de armonizar el éxito de los sectores económicos (como el turismo, el urbanismo o la vivienda —su explotación turística, por ejemplo-) con la protección del medio ambiente y del territorio.

Turismo, urbanismo o vivienda son ámbitos materiales que tienen una intensa relación con aquellos otros que se refieren al medio ambiente y a la ordenación del territorio, ya que inciden plenamente sobre los recursos naturales más importantes, el suelo — que tiene un indiscutible valor ambiental-. A la hora de realizar una ponderación global de las necesidades de utilización y explotación del suelo debe recurrirse a las competencias o concretas funciones públicas especialmente articuladas para ello, que son las de «ordenación del territorio» $\mathrm{y}$ «urbanismo». Estas, aun no siendo estrictas funciones ambientales,

que encuentra su cauce en los arts. 128.1 y 33.2 de la Constitución (STC 83/1984 y 37/1987). Las medidas de intervención que ejercen las administraciones públicas sobre la libre iniciativa privada se justifican en la necesidad de proteger otros derechos igualmente dignos de protección, como son los de los consumidores y usuarios (art. 51), o el deber de atender al desarrollo y modernización de todos los sectores económicos (art. 130.1), o la custodia de los recursos naturales (art. 45.2). Así, la libertad de empresa, junto a su dimensión subjetiva, tiene otra objetiva o institucional, en cuanto elemento de un determinado sistema económico, ejerciéndose dentro de un marco general configurado por las reglas que ordenan la economía de mercado y, entre ellas, las que tutelan los derechos de los consumidores, preservan el medio ambiente u organizan el urbanismo y una adecuada utilización del territorio por todos. El derecho del art. 38 de la Constitución no es el de acometer cualquier empresa, sino el de iniciar y sostener en libertad la actividad empresarial, cuyo ejercicio está disciplinado por normas de muy distinto orden. De donde se desprende la no existencia de un derecho absoluto a la libertad de empresa, sino más bien de un condicionamiento de tal derecho, no solo en el plano constitucional, sino, con fundamento en la Constitución, en normas legales o reglamentarias que perfilen su ejercicio, cuya legalidad vendrá dada por referencia a sus normas de cobertura. El Tribunal Supremo ha dicho en la Sentencia de 2 de julio de 2014, que versa sobre el cumplimiento de las condiciones reglamentarias exigibles para los apartamentos turísticos frente a la denegación de la solicitud de una autorización de apertura: "Añadamos únicamente que según reiterada jurisprudencia constitucional, aplicada con frecuencia por esta Sala, ninguno de los dos derechos constitucionales invocados impiden la regulación de la actividad económica y empresarial y de la propiedad privada ni la imposición de limitaciones a las mismas. En el caso de autos la normativa aplicada supone una regulación que, desde el punto de vista constitucional, no puede calificarse de arbitraria o de irrazonablemente restrictiva, al estar basada en la garantía de la seguridad y la sanidad y no resultar impeditiva de la actividad económica pretendida ni abrasiva de la propiedad privada». 
están al servicio de la utilización racional del suelo a través de procesos de planificación de carácter territorial y urbanístico.

Pero además de dichas competencias o funciones públicas, hay otras que también inciden directamente sobre el suelo y el territorio: se trata de la «ordenación del turismo" y de la "vivienda». Tanto una como otra son funciones públicas que han de remitirse forzosamente también a la técnica de planificación territorial como instrumento de protección de cara a ponderar las necesidades de utilización del territorio, al objeto no solo de equilibrar los valores superiores (desarrollo y preservación), sino también de poder garantizar el derecho a una vivienda digna y adecuada y satisfacer las necesidades residenciales básicas. Y ello de la mano de la política social en materia de vivienda ${ }^{23}$ (concretada, entre otras medidas, en la reserva de suelo para vivienda o en los planes estatales de vivienda ${ }^{24}$ ); de la política urbanística de suelo, sobre todo la de rehabilitación, regeneración y renovación urbana; y de la política turística sostenible y responsable. Esta conexión vino recogida en la exposición de motivos de la Ley 8/2013, de 26 de junio, de rehabilitación, regeneración y renovación urbanas y se encuentra en la actualidad en la Ley del Suelo y Renovación Urbana de 2015 (Real Decreto Legislativo 7/2015, de 30 de octubre) ${ }^{25}$.

El principio de desarrollo territorial urbano y sostenible ${ }^{26}$ previsto en el apdo. 2 del art. 3 de la Ley estatal del Suelo de $2015^{27}$, establece que la

23 Véase G. Roger Fernández (2016), «Necesidad de una reorientación recuperadora de las políticas públicas de vivienda para todos los ciudadanos», Revista de Derecho Urbanistico y Medio Ambiente, 307, págs. 77-92.

24 Para favorecer el acceso de los ciudadanos a la vivienda, desde hace ya algunos años el Gobierno aprueba planes estatales de fomento; es el caso del Real Decreto 637/2016, de 9 de diciembre, por el que se prorroga el Plan Estatal de fomento del alquiler de viviendas, la rehabilitación edificatoria, y la regeneración y renovación urbanas 20132016, regulado por el Real Decreto 233/2013, de 5 de abril (en la exposición de motivos se mencionan todos los planes hasta ahora aprobados).

25 Véase D. Fernández de Gata Sánchez (2016), "Conservación de edificios y construcciones, rehabilitación y renovación urbanas», en M. M. Fernando Pablo (dir.), Derecho de la edificación y renovación urbana, Tecnos, págs. 307-329 (págs. 315-329).

26 Sobre el desarrollo de este principio, véase M. Vaquer Caballería (2017), «La consolidación del principio de desarrollo territorial y urbano sostenible en la última década", Revista de Derecho urbanistico y Medio Ambiente, 311, págs. 499-525.

27 La Sentencia del Tribunal Supremo de 29 de julio de 2015 se refiere a la recepción del principio de desarrollo territorial y urbano sostenible en la Ley estatal 8/2007, de suelo, y en el Texto refundido vigente, aprobado por Real Decreto Legislativo 2/2008, de 20 de junio, y señala que dicho principio «pretende desplazar la tradicional concepción desarrollista impulsora de un crecimiento urbano ilimitado por otra que lo controle, insistiendo en la regeneración de la ciudad existente, frente a las nuevas 
política pública de suelo tiene como fin la utilización racional de este recurso conforme al interés general, y además otorga una especial relevancia a que en ese cometido debe armonizarse la economía, el empleo, la cohesión social, la igualdad de trato y de oportunidades, la salud y la seguridad de las personas y la protección del medio ambiente ${ }^{28}$. El apdo. 3 de dicho artículo, más allá de señalar que los poderes públicos deben posibilitar el uso residencial en viviendas constitutivas de domicilio habitual (epígrafe a) o la integración en el tejido urbano de cuantos usos resulten compatibles con la función residencial (epígrafe g), concreta algo muy importante, que es que las autoridades habrán también de valorar, en su caso, la perspectiva turística, permitiéndose y mejorándose el uso turístico responsable (epígrafe j). Y todo ello con el fin último de hacer efectivo el derecho a disfrutar de una vivienda digna y adecuada (apdo. 4, in fine, del art. 3) ${ }^{29}$. Adquiere, por consiguiente, mucha importancia la cuestión de la convivencia de usos residenciales y usos turísticos, situación que se da cuando la vivienda se somete a un uso distinto de su calificación urbanística, como es el caso de la comercialización turística de una vivienda de uso residencial.

Frente a la alarma social y sensación de saturación turística provocada por el uso indiscriminado del alojamiento colaborativo — sobre todo en edificios plurifamiliares de uso residencial en régimen de propiedad horizontal—, la

transformaciones de suelo, si bien partiendo de la premisa de que desde la legislación estatal no se puede imponer un determinado modelo urbanístico... (STS 17 de junio de 2015-recurso de casación 3367/2013)».

28 Sobre las actuaciones de regeneración y renovación sobre el medio urbano, véase $\mathrm{M}$. R. Alonso Ibáñez (2016), "Las actuaciones de regeneración y renovación urbanas», Práctica urbanistica, 138, págs. 42-55; y J. Torres Martínez (2016), «EL Real Decreto Legislativo 7/2015, de 30 de octubre por el que se aprueba el Texto Refundido de la Ley del Suelo y Renovación Urbana. Su especial incidencia en la regulación de la Rehabilitación Urbana», Práctica urbanística, 138, págs. 6-13.

29 Este derecho se integra en el estatuto básico de los ciudadanos, que se define como «el derecho a disfrutar de una vivienda digna, adecuada y accesible, concebida con arreglo al principio de diseño para todas las personas, que constituya su domicilio libre de ruido $\mathrm{u}$ otras inmisiones contaminantes de cualquier tipo que superen los límites máximos admitidos por la legislación aplicable y en un medio ambiente y un paisaje adecuados» (apdo. a) del art. 5). Sobre el derecho básico de la ciudadanía a una vivienda digna, adecuada y accesible: L. Parejo Alfonso y G. Roger Fernández (2008), Comentarios al Texto Refundido de la Ley de Suelo (Real Decreto Legislativo 2/2008, de 20 de junio), Madrid: Iustel; J. González Pérez (2007), Comentarios a la Ley del Suelo, Navarra: Aranzadi (págs. 139-156); y J. Ponce Solé (2015), «Siete consideraciones sobre el derecho a la vivienda, la ciudad y las viviendas vacías: podemos hacer más (y mejor)», Blog de Revista Catalana de Dret Públic, de 20 de marzo de 2015. 
política de turismo responsable tiene que garantizar tanto el uso adecuado de la vivienda (uso residencial) como la posibilidad de su explotación económica (uso turístico), por lo que los poderes públicos, amparados en la competencia urbanística que tengan atribuida, están plenamente legitimados para regular y limitar - mediante la técnica de la zonificación - el alquiler turístico en viviendas en aras a compatibilizar el uso turístico del espacio urbano con el uso residencial, de acuerdo con la función social de la propiedad, la protección del medio ambiente, el principio de desarrollo urbano sostenible, la protección del entorno urbano y los objetivos de política social. Ello no tiene que confundirse con la ordenación concreta del uso de hospedaje en una vivienda, es decir, con la concreta actividad de alojamiento, cuya proyección turística es evidente y cuya competencia corresponde a las autoridades turísticas competentes.

En conclusión, se trata de que instrumentos de planificación territorial, mediante la técnica de la zonificación, regulen desde un punto de vista estrictamente urbanístico y medioambiental el lugar y modo donde los usos turísticos y residenciales hayan de desarrollarse. Así ha sido reconocido — siguiendo la doctrina establecida por la Sentencia del Tribunal Supremo de 27 de julio de 2010 - por la Sentencia 357/2014, de 12 de junio, del Tribunal Superior de Justicia de Cataluña, con ocasión de la pretensión de nulidad de algunos preceptos del Plan Especial de establecimientos de concurrencia pública, hostelería y otros servicios del Distrito de Ciutat Vella, aprobado por el Consejo Plenario del Ayuntamiento de Barcelona, de 23 de julio de 2010 (en el mismo sentido puede verse también la STSJ de Cataluña 199/2014, de 2 de abril).

\section{LAS RESTRICCIONES AL ACCESO A LA COMERCIALIZACIÓN TURÍSTICA EN VIVIENDAS Y SU CONFRONTACIÓN CON LA GARANTÍA DE LA UNIDAD DE MERCADO. ANÁLISIS DE LA SENTENCIA DEL TRIBUNAL CONSTITUCIONAL DE 22 DE JUNIO DE 2017}

Como se ha dicho anteriormente, algunas normativas autonómicas y municipales, además de remitirse a (o utilizar) la técnica de la zonificación para delimitar las áreas destinadas al alquiler turístico, contienen otras restricciones y límites al acceso a la comercialización turística en viviendas, tales como el establecimiento de un techo de plazas, la prohibición de dedicar a esta actividad viviendas de menos de cinco años, el sometimiento a una declaración responsable por un máximo de cinco años en el caso de viviendas plurifamiliares, el veto a formalizar contratos para comercializar habitaciones para este tipo de estancias o la exigencia de un acuerdo de la Junta de Propietarios en viviendas en régimen de propiedad horizontal. Tanto las Autoridades de la Competencia como el Ministerio de Economía y Competitividad han 
manifestado al respecto — como ya se ha advertido- que limitaciones de este calado pueden suponer una confrontación con el principio de libre competencia y establecimiento derivado de la Directiva de servicios del mercado interior de 2006, así como con el principio de libertad de empresa reconocido en el artículo 38 de la CE y con el de garantía de unidad de mercado.

\subsection{La aplicación de la Directiva de servicios en la comercialización turística en viviendas}

La Directiva de Servicios y su transposición en el derecho interno (fundamentalmente, mediante la Ley 17/2009, de 23 de noviembre, sobre el libre acceso a las actividades de servicios y a su ejercicio [en adelante, Ley 17/2009] y la Ley 20/2013, de 9 de diciembre, de garantía de la unidad de mercado [en adelante, Ley 20/2013], que modifica la Ley 17/2009), más allá de perseguir la simplificación administrativa en un proceso de racionalización de estructuras organizativas y de puesta en marcha del sistema de ventanilla única ${ }^{30}$, incide sobre todo en la manera de vertebrarse las relaciones entre la Administración y los prestadores de servicio, en el marco del tránsito de una Administración autorizatoria a una Administración supervisora que garantice la libertad de establecimiento y la libre prestación dentro de la Unión Europea. Como se ha dicho, algunos organismos han advertido que el establecimiento de limitaciones al acceso a la comercialización turística plantea una posible confrontación a los principios que se derivan de la Directiva. Sin embargo, es preciso poner de relieve un dato relevante que afecta al ámbito de aplicación de la Directiva de Servicios, que es la exclusión del mismo de las materias correspondientes a la ordenación del territorio y al urbanismo, de conformidad con su considerando noveno, cuyo tenor literal dice que:

[...] la presente Directiva solo se aplica a los requisitos que afecten al acceso a una actividad de servicios o a su ejercicio. Así, no se aplica a requisitos tales como tráfico rodado, normas relativas a la ordenación del territorio, urbanismo y ordenación rural, normas de construcción, ni a las sanciones administrativas impuestas por no cumplir dichas normas, que no regulan específicamente o no afectan específicamente a la actividad de servicio pero que tienen que ser respetadas por los prestadores en el ejercicio de su actividad económica al igual que por los particulares en su capacidad privada.

30 Sobre los aspectos generales de la ventanilla única, véase J. V. González García (2009), «La transposición de la Directiva de servicios: Aspectos normativos y organizativos en el Derecho español», Revista Española de Derecho Europeo, 32, págs. 469-506 (págs. 504-506). 
Como muy bien ha señalado la STSJ de Cataluña 357/2014, de 12 de junio, antes citada, la Directiva de Servicios:

[...] es aplicable a los requisitos relativos al establecimiento de una actividad de servicio y/o a su ejercicio, siendo su finalidad la de eliminar los obstáculos que se oponen a la libertad de establecimiento de los prestadores en los Estados miembros y a la libre circulación de servicios entre los Estados miembros — considerando (5)—, implicando esta libertad, en concreto, el principio de igualdad de trato, que prohíbe no solo toda discriminación basada en la nacionalidad de un Estado miembro, sino también toda discriminación indirecta basada en otros criterios que puedan conducir, de hecho, al mismo resultado — considerando (65).

Esto significa que la Directiva de Servicios afecta a la regulación de los requisitos de establecimiento de una actividad turística o su ejercicio. Pero una cosa es la regulación de dichos requisitos y otra distinta es la zonificación que pueda llevar a cabo el instrumento de planificación territorial o urbanística al objeto de establecer la intensidad del uso del suelo en una zona para comercializar el uso turístico en viviendas; en este último caso, la finalidad principal es compatibilizar el uso turístico con el uso residencial y con otros usos comerciales al servicio de los residentes, sin incidir ni en el establecimiento ni en el ejercicio de la actividad, ni sin hacer ningún requerimiento que pueda discriminar directa o indirectamente a nacionales de otros Estados miembros de la Unión Europea, toda vez que las normas de los instrumentos de planificación sobre uso del suelo son aplicables a cualquier persona sin distinción alguna por razón de nacionalidad o Estado de establecimiento.

En consecuencia, se aprecian dos situaciones que es preciso diferenciar a efectos de la aplicabilidad de la Directiva de servicios a la comercialización turística en viviendas: a) una, relacionada con el ámbito del urbanismo o la ordenación del territorio (excluido de la aplicación de la Directiva y de la Ley 17/2009 de transposición), que incide sobre la implantación urbanística de las viviendas que puedan destinarse al alquiler turístico, y cuya finalidad es evitar la excesiva y nociva proliferación de turistas en los barrios de uso residencial, es decir, de evitar lo que se conoce como la gentrificación ${ }^{31}$. En este caso, los instrumentos de planeamiento determinan mediante la zonificación ciertas condiciones previas o colaterales al ejercicio de la comercialización turística de las viviendas, del mismo modo que el planeamiento regula otros elementos por la vía de la fijación de estándares u otros procedimientos. b) Y otra, relacionada con la actividad y las

31 Sobre este tema puede verse mi último trabajo (2017), «Un problema actual de la vivienda: uso residencial versus uso turístico", Revista de Derecho Urbanistico y Medio Ambiente, 317, págs. 17-47 (págs. 23-28). 
condiciones de prestación del servicio (sometida a la Directiva y a la legislación de transposición), referida al ámbito del uso o servicio considerado en su estricto sentido, es decir, a la actividad concreta y específica a desarrollar y a sus condiciones de funcionamiento posterior. Desde esta perspectiva se regula el ordinario funcionamiento de la comercialización turística de las viviendas así como su autorización administrativa —en sentido amplio, ya sea con control previo o posterior-. En este caso, el sometimiento a la Directiva de servicios y a la legislación de transposición está fuera de duda, por lo que conviene averiguar qué alcance tiene la aplicación de dicha normativa en la comercialización turística de las viviendas.

2.2. El régimen de intervención administrativa en la actividad de comercialización turística en viviendas

El libre establecimiento de las empresas en cualquier sector de la economía, y por ende en el turismo, no conlleva una menor responsabilidad de las administraciones públicas en relación con la actividad de los emprendedores, sino un cambio en su forma de actuar. La Administración del nuevo Estado regulador y garante ${ }^{32}$ — que actúa bajo el paraguas de la libre competencia y de la liberalización - ha de garantizar y vigilar el comportamiento de los prestadores para asegurar la salvaguarda del interés general, en el marco jurídico de la regulación y a través de la aplicación de fuertes y eficaces mecanismos de control $^{33}$. El camino liberalizador, desregulador y de mayor simplificación no aligera, por consiguiente, ni la posición y responsabilidad del legislador ni la de las administraciones públicas, sino todo lo contrario: así, por un lado, de cara a garantizar la salvaguarda del interés general, se considera necesario no solo una regulación intensa (que puede ser compatible con la autorregulación de las empresas privadas ${ }^{34}$ ), sino además un papel garante del Estado, provisto de los instrumentos normativos y ejecutivos precisos para orientar el funcionamiento del mercado hacia la competencia; y, por otro lado, como refleja la

32 Sobre el significado del modelo de Estado regulador es imprescindible la lectura de Muñoz Machado (20I I: 487-5 I7).

33 A. Nogueira López (2011), "La termita Bolkestein», El Cronista del Estado Social y Democrático de Derecho, 22, págs. 58-70 (pág. 69). La autora critica que la normativa de transposición de la Directiva «no ha hecho un esfuerzo de adaptación a ese nuevo entorno en el que la intervención de la Administración ha basculado hacia un control operativo que debe ser objeto de una regulación que defina sus garantías, efectos y procedimiento".

34 Sobre la autorregulación en el ámbito del alquiler turístico, véase Rodríguez Font (2017: 422-424). 
legislación del régimen jurídico de las administraciones públicas, se impone un refuerzo de la responsabilidad de las administraciones públicas, ya que tienen la obligación de velar por el cumplimiento de los requisitos aplicables según la legislación correspondiente (antiguo segundo párrafo del art. 39 bis de la Ley 30/1992, de 26 de noviembre, y vigente art. 4 de la Ley 40/2015, de 1 de octubre).

El punto de partida de la Directiva de servicios de 2006 es la libre iniciativa económica. Sin embargo, esa libertad no es ilimitada, sino que puede ser condicionada siempre que exista una justificación o una razón poderosa para restringir legítimamente la libertad (Fernández Torres, 2011) ${ }^{35}$. La Directiva de servicios prevé que se puede incidir sobre la libertad atendiendo a tres requisitos: no discriminación, justificación y motivación de la intervención por una razón imperiosa de interés general y proporcionalidad. Concretamente, el art. 9 de la Directiva prevé que solo podrá supeditarse el acceso a una actividad de servicios y su ejercicio a un régimen de autorización administrativa cuando dicho régimen: a) no sea discriminatorio para el prestador; $b$ ) resulte indispensable por una razón imperiosa de interés general ${ }^{36} ; \mathrm{y} c$ ) no pueda conseguirse el objetivo perseguido mediante una medida menos restrictiva, porque un control a posteriori se produciría demasiado tarde para ser realmente efi$\mathrm{caz}^{37}$. La transposición que de este precepto realiza el art. 5 de la Ley 17/2009

35 Véase J. R. Fernández Torres (2011), «Regímenes de intervención administrativa: autorización, comunicación previa y declaración responsable», Revista Catalana de Derecho Público, 42, págs. 85-114 (págs. 89-95). Además, véase también V. Aguado i Cudolà (2012), «Libertad de establecimiento de los prestadores de servicios: autorización, declaración responsable, comunicación previa y silencio positivo", en V. Aguado i Cudolà y B. Noguera de la Muela (dirs.), El impacto de la Directiva de Servicios en las Administraciones Públicas: aspectos generales y sectoriales (págs. 67-89), Barcelona: Atelier.

36 Considera la jurisprudencia comunitaria que son razones imperiosas de interés general: el orden público y la seguridad pública; protección civil; salud pública; sanidad animal; régimen de la seguridad social; protección de consumidores, usuarios y trabajadores; exigencias de buena fe en las transacciones comerciales; propiedad intelectual e industrial; lucha contra el fraude; protección del medio ambiente y entorno urbano; objetivos de política social y cultural; conservación del patrimonio histórico y artístico nacional.

37 Sobre el acceso a las actividades de servicio y su ejercicio, véase T. de la QuadraSalcedo Fernández del Castillo (2010), «Libertad de establecimiento y de servicios: ¿Reconocimiento mutuo o país de origen?», Revista Española de Derecho Administrativo, 146, págs. 221-263 (pág. 253). El autor señala críticamente que «el resultado puesto en pie por la Unión privilegia y asume la función de facilitar el libre acceso a las actividades de servicio y se olvida completamente como tal Unión de las razones 
prevé que en ningún caso el acceso a una actividad de servicios se sujetará a un régimen de autorización cuando sea suficiente una comunicación o una declaración responsable del prestador. El principio nuclear sobre el que gira el acceso y ejercicio de las actividades de servicios es, pues, la libertad, quedando como condicionantes a los límites de esa libertad los principios de no discriminación, justificación o motivación de la intervención administrativa (razón imperiosa de interés general $)^{38} \mathrm{y}$ proporcionalidad.

a) La incidencia del principio de necesidad y proporcionalidad de la Ley de garantía de unidad de mercado en la regulación de las actividades económicas

La Ley 20/2013 de garantía de la unidad de mercado incide sobre la Ley 17/2009 y afecta notablemente los regímenes de intervención administrativa. Como ha reconocido la Sentencia del Tribunal Constitucional, de 22 de junio de 2017 (STC 79/2017), que estima parcialmente el recurso presentado por el Parlamento de Cataluña contra varios preceptos de la Ley 20/2013, esta «establece una serie de principios y directrices que tienen como resultado fundamental promover un funcionamiento más libre del mercado, pues someten a las autoridades regulatorias competentes, para el supuesto en que establezcan límites al acceso a una actividad económica o su ejercicio o exijan el cumplimiento de requisitos para el desarrollo de una actividad económica, a mayores condicionamientos y restricciones de los existentes hasta la aprobación de la norma. Tales condicionamientos y restricciones a la capacidad interventora de los poderes públicos en la economía, entrañan una «desregulación» del mercado». Viene a decir el Tribunal Constitucional en la citada sentencia que uno de los objetivos de la Ley 20/2013 es eliminar los obstáculos y trabas derivados del crecimiento de la regulación en el ejercicio de la libertad de iniciativa

imperiosas de interés general que pueden establecer los Estados; éstas solo se ven como posibles obstáculos».

38 A partir de la razón definida e interpretada por la jurisprudencia del Tribunal de Justicia de las Comunidades Europeas (véase nota anterior), el art. 3.11 de la Ley 17/2009 establece una lista «cerrada» de cuáles son las razones imperiosas de interés general: el orden público, la seguridad pública, la protección civil, la salud pública, la preservación del equilibrio financiero del régimen de la seguridad social, la protección de los derechos, la seguridad y la salud de los consumidores, de los destinatarios de servicios y de los trabajadores, las exigencias de buena fe en las transacciones comerciales, la lucha contra el fraude, la protección del medio ambiente y del entorno urbano, la sanidad animal, la propiedad intelectual e industrial, la conservación del patrimonio histórico y artístico nacional y los objetivos de política social y cultural. 
económica dentro de un mercado que se quiere único; y lo hace extendiendo la regulación contenida en la Ley 17/2009 a todas las actividades económicas, entre las que se encuentra obviamente la turística, cuyo sometimiento, sin embargo, a la Directiva de servicios es desde su origen, como consecuencia de la transposición tanto por la legislación estatal mediante la Ley 17/2009 como por las legislaciones autonómicas de la mencionada Directiva, de cuyo apdo. 33 se desprendía desde el inicio su aplicación a los «servicios turísticos» ${ }^{39}$.

La Ley 17/2009 sienta un precedente en materia de unidad de mercado para el sector servicios (incluido el turismo); pero con la Ley 20/2013 la regulación se extiende a todas las actividades económicas, de modo que se aplicará también a los sectores económicos expresamente excluidos de la Directiva de servicios así como a la circulación de productos ${ }^{40}$. La Ley 20/2013 parte del principio general de libre iniciativa económica, pero es mucho más liberalizadora que la Directiva 123/2006 de servicios y su transposición, ya que, además de ampliar los sectores sujetos a liberalización (art. 16), regula el principio de necesidad y proporcionalidad de las actuaciones de las autoridades competentes (art. 5) así como su instrumentación (art. 17) ${ }^{41}$.

39 El apdo. 33 de la Directiva de Servicios señala lo siguiente: «En la presente Directiva, el concepto de "servicio" incluye actividades enormemente variadas y en constante evolución; entre ellas se cuentan las siguientes: [...] las agencias de viajes. Los servicios destinados a los consumidores quedan también incluidos, como los relacionados con el turismo, incluidos los guías turísticos, [...]».

40 Así lo ha reconocido la STC de 22 de junio de 2017, antes citada: «La Ley 20/2013 ha desbordado el ámbito material de la Directiva 2006/123/CE, de 12 de diciembre, relativa a los servicios en el mercado interior - y al que se refiere una de sus Leyes de transposición, la Ley 17/2009, de 23 de noviembre, sobre el libre acceso a las actividades de servicio y su ejercicio-, pues ha incluido en su ámbito de aplicación todas las actividades económicas en condiciones de mercado (art. 2 de la Ley 20/2013), incluyendo no solo las actividades que se refieren a la prestación de servicios sino también las que se refieren a la elaboración y comercialización de productos. Así lo subraya el preámbulo de la propia Ley 20/2013 cuando afirma que "la Ley 17/2009, de 23 de noviembre, sienta un precedente en materia de unidad de mercado para el sector servicios que se considera debe extenderse a todas las actividades económicas. Así, esta Ley [la Ley 20/2013] se aplicará también a los sectores expresamente excluidos de la Directiva de Servicios (como por ejemplo las comunicaciones electrónicas; el transporte, las empresas de trabajo temporal, la seguridad privada, etc.) y a la circulación de productos"”.

41 Sobre el alcance y contenido del principio de necesidad y proporcionalidad, véase G. Fernández Farreres (2014), «Unidad de Mercado y libertades de empresa y circulación en la Ley 20/2013, de 9 de diciembre», Revista Española de Derecho Administrativo, 63, págs. 109-144 (págs. 122-133). Y sobre el alcance de dichos principios en el 
En concreto, el principio de necesidad y proporcionalidad ${ }^{42}$ establece que cuando las actuaciones de las autoridades competentes fijen límites al acceso a una actividad económica o a su ejercicio o exijan el cumplimiento de requisitos para el desarrollo de una actividad económica, deben hacerlo en las condiciones establecidas en el propio art. 5 de la Ley 20/2013, que son: a) en primer lugar, la exigencia de motivar la necesidad de tales límites y requisitos con fundamento en la salvaguarda de alguna de las razones imperiosas de interés general que específicamente se recogen en el art. 3.11 de la Ley 17/2009 (apdo. 1), y que son las siguientes: «el orden público, la seguridad pública, la protección civil, la salud pública, la preservación del equilibrio financiero del régimen de la seguridad social, la protección de los derechos, la seguridad y la salud de los consumidores, de los destinatarios de servicios y de los trabajadores, las exigencias de buena fe en las transacciones comerciales, la lucha contra el fraude, la protección del medio ambiente y del entorno urbano, la sanidad animal, la propiedad intelectual e industrial, la conservación del patrimonio histórico y artístico nacional y los objetivos de política social y cultural»; y b) en segundo lugar, la exigencia de que cualquier límite y requisito establecido por la autoridad competente sea proporcionado a la razón imperiosa de interés general invocada, y habrá de ser tal que no exista otro medio menos restrictivo o distorsionador para la actividad económica (apdo. 2).

Como ha manifestado la STC de 22 de junio de 2017, el principio de necesidad supone «una limitación de aquellas razones o finalidades legítimas que pueden justificar que los poderes públicos autonómicos afecten al libre acceso y al libre ejercicio de las actividades económicas», pues el precepto establece, por remisión al art. 3.11 de la Ley 17/2009, una relación tasada de las razones o finalidades que pueden justificar la intervención en las actividades económicas por parte de los poderes públicos al ejercer sus propias competencias sectoriales (por ejemplo, sobre vivienda o turismo), «restringiendo su capacidad de promover, mediante el establecimiento de requisitos o límites sobre el ejercicio de la actividad económica, cualquier

ámbito del turismo, C. R. Marzal Raga (2014), «La unidad de mercado en materia turística», en Ma. J. Alonso Mas (dir.), El nuevo marco jurídico de la unidad de mercado. Comentarios a la Ley de garantía de la unidad de mercado (págs. 705-743), Madrid: La Ley-Wolters Kluwer.

42 El principio de necesidad y proporcionalidad está a su vez recogido en los apdos. 1, 2 y 3 del art. 129 de la Ley 39/2015, de 1 de octubre, del procedimiento administrativo común de las administraciones públicas, que lleva por título «Principios de buena regulación». Concretamente, se hace referencia a la aplicación de dichos principios en el ejercicio de la iniciativa normativa, tanto legislativa como reglamentaria. 
otra finalidad constitucionalmente legítima que no se encuentre recogida en el listado del artículo 3.11 de la Ley 17/2009».

Pero, además, debe tenerse en cuenta también que el sometimiento de todas las regulaciones públicas que afecten al libre acceso o al libre ejercicio de las actividades económicas está sujeto, a la vez, al denominado principio de proporcionalidad, principio que, como dice la citada sentencia, «exige someter aquellas regulaciones a la comprobación de que sean proporcionadas a la razón imperiosa de interés general invocada y a la comprobación de que no exista otro medio menos restrictivo o distorsionador para la actividad económica». En este punto, la mencionada sentencia advierte que ello supone un sometimiento a:

[...] un escrutinio más incisivo que aquel que se deriva directamente del art. $38 \mathrm{CE}$, pues, de acuerdo con la doctrina de este Tribunal que ha interpretado este último precepto, «cuando se trata de regulaciones que afectan al ejercicio de una actividad empresarial, sin afectar al propio acceso a la misma» el canon de constitucionalidad empleado por la jurisprudencia de este Tribunal permite verificar si esas medidas son "constitucionalmente adecuadas", esto es, si la medida cuestionada «constituye una medida adecuada para la consecución de un fin constitucionalmente legítimo, sin que le corresponda a este Tribunal ir más allá, pues ello supondría fiscalizar la oportunidad de una concreta elección del legislador de una legítima opción política» (STC 53/2014, de 10 de abril, FJ 7) [STC 35/2016, de 3 de marzo, FJ 4].

La Ley 20/2013, una vez establecido el principio general de necesidad y proporcionalidad de las actuaciones de las autoridades competentes (art. 5), desciende a un plano más concreto y reglamenta la instrumentación de dicho principio en relación con aquellas regulaciones públicas que establecen la exigencia de una autorización, de una declaración responsable y de una comunicación (art. 17). Como se ha visto, el art. 5 restringe las razones y fines que pueden legitimar el establecimiento de condiciones y requisitos al acceso y al ejercicio de las actividades económicas, y exige no solo motivar la necesidad de tales límites con fundamento en algunas de las razones tasadas sino también justificar su proporcionalidad a la razón invocada (y comprobar que no exista otra medida menos restrictiva). Pero el art. 17 da un paso más, ya que desarrolla la aplicación del principio de necesidad y proporcionalidad cuando la regulación establezca la exigencia de alguno de los distintos medios de control que afectan al acceso o al ejercicio de la actividad económica; de modo que, cuando las autoridades competentes hayan de fijar en concreto dichos medios, podrán elegir entre una comunicación, una declaración responsable o una autorización, en función del interés general a proteger, de los requisitos que, en su caso, se exijan para la salvaguarda de dicho interés general y en atención 
a la naturaleza de la actividad y de si el medio de intervención se dirige a la propia actividad o a la infraestructura física.

Así, en primer lugar, en el caso de aquellas regulaciones públicas que establezcan la exigencia de una autorización, el art. 17.1, además de prever la reserva de ley para el régimen de autorización ${ }^{43}$, restringe aún más aquellas concretas razones imperiosas de interés general que pueden justificar la exigencia de autorización. En particular, respecto a los operadores económicos, solo se puede exigir aquella "por razones de orden público, seguridad pública, salud pública o protección del medio ambiente en el lugar concreto donde se realiza la actividad»; y respecto a las instalaciones o infraestructuras físicas necesarias para el ejercicio de actividades económicas, solo se puede exigir autorización "cuando sean susceptibles de generar daños sobre el medio ambiente y el entorno urbano, la seguridad o la salud pública y el patrimonio histórico-artístico». Asimismo se establecen además dos supuestos adicionales que pueden justificar la exigencia de una autorización: cuando por la escasez de recursos naturales, la utilización de dominio público, la existencia de inequívocos impedimentos técnicos o en función de la existencia de servicios públicos sometidos a tarifas reguladas, el número de operadores económicos del mercado sea limitado; y cuando así lo disponga la normativa de la Unión Europea o tratados y convenios internacionales, incluyendo la aplicación, en su caso, del principio de precaución. En definitiva, y tal como se concluye en la STC de 22 de junio de 2017, «en el caso de las autorizaciones, las razones imperiosas de interés general que las justifican no serían todas aquellas a las que se remite el art. 5 de la Ley 20/2013, y que se contienen en el art. 3.11 de la Ley 17/2009, de 23 de noviembre, sino sólo aquellas razones explícitamente recogidas en el propio art. 17.1». Se limitan, por tanto, las razones de interés general que pueden justificar la intervención mediante una autorización y se obliga a motivar por qué no se recurre a un medio menos restrictivo cuando se dan esas razones de interés general. Para adaptar la Ley 17/2009 a la instrumentación del principio de necesidad y proporcionalidad, la Ley 20/2013 modifica paralelamente el apartado b) del art. 5 de la Ley 17/2009 que afecta a la definición de la «necesidad» a los efectos de que la autoridad competente pueda imponer a los operadores un régimen de autorización sobre el acceso o el ejercicio de una actividad, incluyendo ahora las concretas razones imperiosas de interés general que justificarían su exigencia: «por razones de orden público, seguridad pública, salud pública, protección del

43 Se prevé reserva de ley para el régimen de autorización, es decir, se exige que la concurrencia de los principios de necesidad y proporcionalidad se motiven suficientemente en la propia ley que establezca dicho régimen, salvo que este se exija por norma comunitaria o tratado internacional, en cuyo caso podrá estar previsto en norma de rango inferior a la Ley (primer párrafo del apdo. 1 del art. 17 de la Ley 20/2013). 
medio ambiente, o cuando por la escasez de recursos naturales o la existencia de inequívocos impedimentos técnicos limiten el número de operadores económicos del mercado».

En segundo lugar, el art. 17.2 regula la instrumentación del principio de necesidad y proporcionalidad en relación con aquellas regulaciones públicas que exijan la presentación de una declaración responsable; y se establece que concurren dichos principios cuando en la normativa se exija el cumplimiento de requisitos justificados por alguna razón imperiosa de interés general y sean proporcionados.

En tercer lugar, el art. 17.3 regula la instrumentación del principio de necesidad y proporcionalidad en relación con aquellas regulaciones públicas que exijan la presentación de una comunicación, y tal exigencia solo se podrá dar cuando, por alguna razón imperiosa de interés general, las autoridades precisen conocer el número de operadores económicos, las instalaciones o las infraestructuras físicas en el mercado.

En síntesis, lo que acaba de exponerse supone el condicionamiento de aquellos mecanismos de intervención administrativa previa que corresponde establecer a las comunidades autónomas en ejercicio de sus competencias. Y tal y como subraya la STC de 22 de junio de 2017, «ciertamente, el mayor condicionamiento lo establece la Ley 20/2013 en relación con las autorizaciones, pues además de someterlas al principio de proporcionalidad, restringe las razones que las justifican y exige que la concurrencia de los principios de necesidad y proporcionalidad se motive suficientemente en la propia Ley» ${ }^{44}$.

44 No puede dejar de mencionarse que hasta la STC de 22 de junio de junio de 2017, el principio de necesidad y proporcionalidad debía entenderse sin perjuicio del principio de eficacia nacional establecido en los arts. 19 y 20 de la Ley 20/2013, que ha sido, sin embargo, declarado inconstitucional y nulo. El principio de eficacia nacional suponía que el marco regulatorio de cada comunidad autónoma extendía sus efectos en todo el territorio del Estado, pues, según decía el art. 19 de la Ley 20/2013, bastaba con cumplir los requisitos de acceso en el lugar de origen, incluso cuando la actividad económica no estuviese sometida a requisito alguno en dicho lugar, lo que suponía una generalización del régimen de intervención menos restrictivo. La Sentencia citada declara su inconstitucionalidad «tanto por exceder el alcance de la competencia estatal reconocida en el art. 149.1.13 CE como por vulnerar el principio general de territorialidad de las competencias autonómicas, al permitir la aplicación en un mismo lugar del territorio nacional de normativas diferenciadas para aquellos operadores económicos que únicamente se diferencian por su procedencia». Como ya expuso J. Tornos Mas (2014) en su momento (http://idpbacelona.blogspot.com.es/, 17 de diciembre de 2013), este principio comportaba una situación que podía generar lo que se ha dado a conocer como dumping regulatorio, ya que cualquier operador 
A modo de conclusión, pues, destacan dos aspectos de la Ley de garantía de unidad de mercado que merecen resaltarse: uno (art. 5), el sometimiento de las regulaciones de los poderes públicos que restringen el libre acceso y el libre ejercicio de la actividad económica a mayores exigencias, como son la enumeración tasada de las razones imperiosas de interés general que justifican tales restricciones (principio de necesidad) y el sometimiento de estas al principio de proporcionalidad. Y otro (art. 17), el sometimiento de aquellas regulaciones limitadoras cuando hayan de requerir mecanismos de intervención administrativa a distintos niveles de exigencia: a) en el caso del régimen de autorización, a condiciones incluso más exigentes que las anteriores apuntadas, como son, además del principio de proporcionalidad, la reserva de ley y una mayor restricción de las razones imperiosas de interés general; b) y en el caso de exigir el régimen de declaración responsable o comunicación, al cumplimiento de menores condiciones (para la declaración, de requisitos justificados por alguna razón imperiosa de interés general y que sean proporcionados; y para la comunicación, a que, por alguna razón imperiosa de interés general, se considere necesario conocer el número de operadores económicos, las instalaciones o las infraestructuras físicas en el mercado).

b) Aplicación del principio de necesidad y proporcionalidad en la comercialización turística en viviendas

$\mathrm{Al}$ proyectar estos aspectos que acabamos de ver en el ámbito turístico, concretamente en la comercialización turística en viviendas, no puede obviarse la incidencia del principio de necesidad y proporcionalidad, así como de su instrumentación, en la regulación que ha de llevar a cabo el legislador autonómico de esta actividad económica. Debe partirse del hecho de que las actividades de hospedaje que se desarrollan en la comercialización turística se llevan a cabo precisamente a través de instalaciones o infraestructuras físicas, es decir, en viviendas, por lo que la eventual exigencia de un régimen de autorización para permitir el acceso a dicha actividad económica está sometida a

legalmente establecido, o cualquier bien legalmente producido y puesto en circulación, podría ejercer la actividad económica o circular en todo el territorio nacional sin que cupiese en principio exigirles nuevas autorizaciones o trámites adicionales de otras autoridades competentes. Del mismo autor (2014), «La Ley 20/2103, de 9 de diciembre, de garantía de la unidad de mercado. En particular, el principio de eficacia», Revista d'estudis autonòmics i federals, 19, págs. 144-177 (pág. 160). Al respecto, véase también Fernández Farreres (2014: 133-144), y C. Lence Reija (2017), «La tutela de la libertad de empresa frente a intervenciones administrativas desproporcionadas", Revista General de Derecho Administrativo, 46, 39 págs. (págs. 29-34). 
un condicionamiento importante, que es que la actividad sea susceptible «de generar daños sobre el medio ambiente y el entorno urbano, la seguridad o la salud pública y el patrimonio histórico-artístico» (apdo. 1.b) del art. 17 de la Ley 20/2013). De no ser así, el acceso habrá de sujetarse a un régimen menos restrictivo para la libertad, de declaración responsable o de comunicación, cumpliendo con los requisitos establecidos respectivamente en los apdos. 2 y 3 del citado artículo, vistos más arriba ${ }^{45}$.

La mayoría de las regulaciones autonómicas sobre la comercialización turística en viviendas han establecido un régimen de declaración responsable para el acceso a esta actividad o su ejercicio, o para las instalaciones o infraestructuras físicas para el ejercicio de esta actividad, por lo que las autoridades competentes habrán tenido que comprobar, en aplicación del apdo. 2 del art. 17 de la Ley 20/2013, la concurrencia del principio de necesidad y proporcionalidad para poder requerir la declaración responsable, concurrencia que se da "cuando en la normativa se exija el cumplimiento de requisitos justificados por alguna razón imperiosa de interés general y sean proporcionados». Estas razones imperiosas son las que se detallan en el art. 3.11 de la Ley 17/2009, a las que se ha hecho referencia anteriormente:

[...] el orden público, la seguridad pública, la protección civil, la salud pública, la preservación del equilibrio financiero del régimen de seguridad social, la protección de los derechos, la seguridad y la salud de los consumidores, de los destinatarios de servicios y de los trabajadores, las exigencias de la buena fe en las transacciones comerciales, la lucha contra el fraude, la protección del medio ambiente y del entorno urbano, la sanidad animal, la propiedad intelectual e industrial, la conservación del patrimonio histórico y artístico nacional y los objetivos de la política social y cultural.

De la lectura de estas razones, se deduce que algunas de ellas pueden verse sin duda afectadas, directa o indirectamente, por la comercialización turística en viviendas, tales como el orden público, la lucha contra el fraude, la seguridad de los consumidores, la protección del medio ambiente, la protección del entorno urbano y los objetivos de la política social y cultural. Hay que puntualizar que, entre estos objetivos de la política social y cultural, pueden tener cabida aquellos principios y derechos que son fundamento de dicha política, tales como el derecho al domicilio libre de inmisiones, el derecho

45 Sobre la exigencia de autorización en el ámbito turístico impuesta por la legislación canaria y su confrontación con el principio de libre competencia, véase de A. Domínguez Vila (2017), «Turismo, Derecho comunitario y doctrina del Tribunal», Revista de Derecho urbanistico y Medio Ambiente, 316, págs. 69-111. 
a una vivienda digna, el desarrollo urbano sostenible, la función social de la propiedad o la convivencia armónica entre turistas y residentes. Por tanto, que el legislador autonómico, en ejercicio de sus competencias sobre turismo, exija una declaración responsable para el acceso a la comercialización turística en viviendas puede justificarse en alguna de estas razones imperiosas recién mencionadas, siempre que se motive su invocación y sean proporcionadas, incluso cuando estas razones no se encuentran concretamente enumeradas en la lista del art. 3.11 de la Ley 17/2009, como ha concluido la STC de 22 de junio de 2017, con ocasión del enjuiciamiento de si la lista cerrada a la que se hace referencia tenía un efecto restrictivo sobre las competencias autonómicas que inciden en el ejercicio de las actividades económicas:

[...] la enumeración que se realiza en el art. 3.11 de la Ley 17/2009, es lo suficientemente abierta en sus términos como para que quepan dentro de aquella los diferentes objetivos que se pueden querer promover a través del amplio elenco de competencias autonómicas. Ello se refleja en el hecho de que más allá de la genérica afirmación de que la norma, al establecer un numerus clausus de supuestos, excluye otros posibles supuestos legítimos, no se ha alegado por la parte recurrente cuáles serían esos posibles supuestos que quedan fuera de la enumeración recogida en los preceptos referidos.

Un problema que aquí se plantea es cuando se establece una limitación temporal en el propio título habilitante, por ejemplo, cuando la actividad queda sometida a una declaración responsable por un máximo de cinco años en caso de viviendas plurifamiliares, como hace la legislación de las Islas Baleares (Ley 6/2017, de 31 de julio, de modificación de la Ley 8/2012, de 19 de julio de turismo, relativa a la comercialización de estancias turísticas en viviendas). En este caso, no se trata de un requisito que esté específicamente ligado a la concreta instalación o infraestructura física en que se desarrolla la actividad, sino que se está limitando temporalmente la propia actividad, restringiéndose —una vez superado el plazo establecido - la posibilidad de comercializar el alquiler. Dicho requisito temporal, en tanto que impide el ejercicio de la actividad, puede suponer una vulneración del principio de necesidad y proporcionalidad si no se justifica adecuadamente su implantación, es decir, si no se motiva por qué no se recurre a un medio menos restrictivo cuando se dan las razones imperiosas de interés general que pueden implicar una intervención limitadora.

La Ley de garantía de unidad de mercado no solo regula la instrumentación del principio de necesidad y proporcionalidad, mediante el establecimiento de distintos condicionamientos a los medios de intervención administrativa de acceso a las actividades económicas (autorización, declaración responsable y comunicación) para que estos puedan ser establecidos por las autoridades competentes (art. 17), sino que, como ya se ha visto, regula el 
propio principio de necesidad y proporcionalidad de las actuaciones de dichas autoridades, requiriéndose que cuando o bien se establezcan límites al acceso o al ejercicio de la actividad de conformidad con lo que se prevé en el art. 17 o bien se exija el cumplimiento de requisitos para el desarrollo de la actividad, dichos límites y requisitos habrán de justificarse (su necesidad) por alguna razón imperiosa de interés general y habrán de ser proporcionados (art. 5).

Aplicado a la comercialización turística en viviendas, esto significa que el legislador, en ejercicio de sus competencias, además de poder exigir una declaración responsable para el acceso a dicha actividad económica si se justifica en alguna de las razones imperiosas de interés general, se motiva su invocación y se comprueba su proporcionalidad — como acaba de verse-, puede también exigir el cumplimiento de requisitos para el desarrollo de la actividad; es decir, que de acuerdo con el art. 5 de la Ley 20/2013, las autoridades competentes pueden imponer requisitos, deberes, prohibiciones, restricciones y limitaciones a dicha actividad, «siempre que se justifiquen en la salvaguarda de alguna razón imperiosa de interés general y siempre que concurran los principios de necesidad y proporcionalidad», como ha reconocido la STC de 22 de junio de 2017. Merece la pena destacar en este sentido las clarificadoras palabras de dicha sentencia cuando enjuicia la constitucionalidad del art. 17.1 de la Ley 20/2013:

Si bien las Comunidades Autónomas han visto restringido el uso de determinados instrumentos de control administrativo previo como es la exigencia de autorizaciones, ello no les impide imponer - en ejercicio de sus competencias y en atención al desarrollo de políticas propias- requisitos materiales al acceso y al ejercicio de las actividades económicas dirigidos a la salvaguarda de aquellos objetivos legítimos que exceden de los enumerados en el art. 17.1. Requisitos cuyo cumplimiento por los operadores económicos podrá ser controlado por la administración competente a través de otros mecanismos de intervención, previa o posterior, fuera de la autorización. Así, por ejemplo, las razones imperiosas de interés general justificarán la exigencia de mecanismos de intervención previos como son la presentación de declaraciones responsables o de comunicaciones previas, conforme prescriben los apartados 2 a 4 del referido artículo 17 de la Ley 20/2013. [...]. Es por tanto conforme con la norma fundamental que el Estado promueva el objetivo económico de que se reduzcan las cargas administrativas para el acceso y ejercicio de una actividad económica, sin que ello suponga el menoscabo de aquellos intereses a proteger, pues la norma permite bien el establecimiento de mecanismos de control distintos que tendrán lugar con carácter previo (declaración responsable, comunicación previa), bien el establecimiento de condiciones de ejercicio de la actividad económica cuyo cumplimiento siempre podrá ser controlado con posterioridad. En consecuencia, debemos desestimar la impugnación del apartado 1 del art. 17 de la Ley 20/2013. 
Por todo lo anterior, requisitos limitativos como los que han introducido las autoridades competentes en materia de turismo, tales como exigencia de contadores individuales de agua y otros suministros, la necesidad de contar con un acuerdo de la junta de propietarios en viviendas en edificios plurifamiliares, la imposibilidad de formalizar contratos por habitaciones, la limitación a cinco años de la declaración responsable en el caso de las plurifamiliares o la prohibición de alquilar viviendas de menos de cinco años, son efectivamente medidas restrictivas para el ejercicio y el desarrollo de la actividad, cuya vulneración o no del principio de necesidad y proporcionalidad derivado de la garantía de la unidad de mercado habrá de valorarse en función de su justificación en la salvaguarda de alguna de las razones imperiosas de interés general que puedan invocarse. A mi juicio, en estos casos se trata de medidas que están justificadas en algunas de las razones imperiosas de interés general que se establecen y, por lo tanto, son restricciones que no contravienen la Ley de garantía de unidad de mercado; así, por ejemplo, la exigencia de contadores individuales de agua y otros suministros se justifica en la «seguridad de los consumidores» o en la "protección del medio ambiente» ${ }^{46}$; la necesidad de contar con un acuerdo de la junta de propietarios en viviendas en edificios plurifamiliares se justifica en el «orden público»" ${ }^{47}$; la prohibición de alquilar

46 Es preciso subrayar que en Mallorca ha sido usual que en las comunidades de propietarios existan contadores comunes de agua. Para justificar la imposición de contadores individuales, la exposición de motivos de la Ley 6/2017 de las Islas Baleares establece lo siguiente: «Asimismo, teniendo en cuenta la necesidad de proteger adecuadamente el medio ambiente y hacer un uso sostenible de las infraestructuras y de los recursos de las Illes Balears, así como de protección de los turistas y las turistas como personas consumidoras y usuarias, se exige a todas las viviendas residenciales que quieran comercializar estancias turísticas el requisito de disponer de un certificado energético concreto, en función de la antigüedad del inmueble. Asimismo, se determina que solo podrán presentar nuevas declaraciones responsables de inicio de actividad turística los propietarios que dispongan de medidores o contadores individuales de agua, y de otros suministros energéticos, si procede».

$47 \mathrm{Al}$ respecto, es muy interesante la justificación de la exposición de motivos de la Ley 6/2017 de las Islas Baleares: «Volviendo estrictamente a las viviendas de uso residencial sometidas al régimen de propiedad horizontal, debe mencionarse que es cierto que el artículo 33 de la Constitución reconoce, en la sección de los derechos y deberes de la ciudadanía, el derecho a la propiedad privada, lo cual se podría considerar que concede el derecho a cualquier uso del inmueble, pero también es cierto que el derecho a la propiedad privada nace delimitado por su función social. Por ello, no tan solo diferentes configuraciones legales que tengan que ver con el urbanismo, la ordenación del territorio, el medio ambiente, etc., pueden limitar el derecho de propiedad, sino que también las relaciones de vecindad (como las comunidades de propietarios) pueden 
viviendas de menos de cinco años de antigüedad se justifica en la «lucha contra el fraude» (la especulación) ${ }^{48}$; y la limitación de la declaración responsable

limitarlo por razones diversas. Estas razones pueden afectar incluso a derechos constitucionales fundamentales, tales como el derecho a la intimidad personal y familiar, el derecho a la seguridad de los residentes habituales o el derecho al medio ambiente adecuado. En este sentido, se tiene que tener en cuenta que las personas usuarias de estancias turísticas irán cambiando cada pocos días o semanas; que tendrán acceso a zonas comunes y harán uso de ellas; que sus usos y dinámica horaria podrían no coincidir con los de los residentes habituales, etc. Vistos estos efectos directos sobre el vecindario residente y con independencia de la posibilidad de interposición de las acciones que la Ley 49/1960, de 21 de julio, de propiedad horizontal, en su artículo 7.2, otorga a las comunidades de propietarios, se impone la necesidad de que los poderes públicos procuren, mediante una intervención delimitadora general, no solo intentar reforzar el deber de vigilancia o control de los comercializadores respecto de la clientela e impedir que se produzcan molestias, sino velar por que el resto de miembros de la comunidad de propietarios puedan tener una potestad efectiva de decisión respecto a la posibilidad de admitir o no la comercialización turística de una o de varias viviendas pertenecientes a la comunidad, lo que les afectará directamente. Se tiene que partir de la idea de que esta posibilidad genérica en edificios sometidos a propiedad horizontal es nueva en el archipiélago y, por lo tanto, la falta de previsión expresa al respecto en los títulos constitutivos o los estatutos de las comunidades de propietarios puede ser frecuente. Ello conduce a la necesidad de dotar a las personas propietarias en régimen de propiedad horizontal, por medio de una ley, de instrumentos realmente claros y efectivos para determinar si se permite o no la comercialización turística en el edificio, lo cual pasa por atender, no tan solo a lo que disponga el título constitutivo o los estatutos, sino por reconocer capacidad efectiva a los acuerdos tomados válidamente por las juntas de propietarios al respecto. Por lo tanto, esta norma parte de exigir que en primer lugar se estará a lo que pudieran determinar los estatutos, en el sentido de que si determinan la no posibilidad de uso de los inmuebles para uso diferente al de vivienda, no se podrá llevar a cabo la comercialización turística. También establece que, si admiten expresamente la posibilidad de comercialización turística, esta se podrá llevar a cabo. Para la modificación de estas previsiones se estará al régimen determinado en la Ley 49/1960, de 21 de julio, de propiedad horizontal. En caso de que los estatutos no establezcan ninguna de estas previsiones, la norma advierte que para permitir llevar a cabo comercializaciones turísticas se estará a un acuerdo de la mayoría de propietarios, adoptado de conformidad con lo que determina el artículo 17.7 de la Ley 49/1960, de 21 de julio, de propiedad horizontal».

48 En los últimos tiempos en Mallorca los inversores compran bloques de viviendas nuevas para dedicarlas al alquiler turístico, y ello además de impedir el derecho de acceso a la vivienda a los residentes produce también un encarecimiento del precio de la vivienda. La exposición de motivos de la Ley 6/2017 de las Islas Baleares justifica la implantación de la medida limitativa relativa a la antigüedad de la vivienda del siguiente 
a cinco años en las plurifamiliares se justifica en «la protección del entorno urbano» ${ }^{49}$. Y sin perjuicio, además, de que dichas restricciones se justifican a la vez en otra razón imperiosa de interés general como es la relativa a los «objetivos de la política social y cultural». Nadie puede dudar que entre los «objetivos de la política social y cultural» se encuentra el derecho al domicilio libre de inmisiones, el derecho a una vivienda digna, el desarrollo urbano sostenible, la función social de la propiedad o la convivencia armónica entre turistas y residentes, de modo que las restricciones que vimos más arriba encuentran en definitiva su evidente acomodo en la importante razón imperiosa de interés general bautizada como «objetivos de la política social y cultural». A dicha razón ha hecho referencia el Tribunal Constitucional en

modo: «Por otra parte, se tiene que hacer mención específicamente a una exigencia de antigüedad que se requerirá a las viviendas de uso residencial que quieran, a partir de ahora, presentar las declaraciones responsables para comercializar estancias turísticas, que será de cinco años durante los cuales, además, el uso tendrá que haber sido residencial privado. Ello, porque, como dice el mismo concepto, tienen que ser viviendas de uso residencial y, por lo tanto, tiene que haber una consolidación previa y real de este uso residencial antes de poder ser comercializada turísticamente. Se trata de evitar saturaciones, especulaciones urbanísticas y otros perjuicios al interés general».

En relación a la cuestión de la temporalidad de la declaración responsable, la exposición de motivos de la Ley 6/2017 de las Islas Baleares justifica su implantación así: «[...] con respecto a la comercialización de estancias turísticas llevada a cabo en viviendas residenciales sometidas al régimen de propiedad horizontal, y en las de las tipologías que se determinen reglamentariamente, se considera necesario fijar, por razones urbanísticas, un límite adicional de temporalidad para el ejercicio de la actividad. Este permiso sería renovable mediante la presentación de una comunicación y de un certificado de adquisición temporal de plazas, pero siempre que se siguieran cumpliendo todos los requisitos legales en el momento de la renovación, como, por ejemplo, que la zona donde se ubicaran siguiera siendo una zona apta para la comercialización de estancias turísticas en viviendas residenciales. Ello, porque con esta ley se regula de manera específica, por primera vez en las Illes Balears, la posibilidad con condiciones de comercialización turística de estas viviendas, en las cuales, por lo tanto, se llevará a cabo una actividad de carácter residencial turístico junto con el estrictamente residencial, lo cual, sumado a la generalmente mayor densidad poblacional por solar respecto de otras tipologías, conduce a la necesidad de que el legislador prevea la posibilidad de que las zonas donde se permita o los criterios urbanísticos o territoriales que se establezcan se puedan ir adaptando a las problemáticas y necesidades urbanísticas que puedan ir surgiendo, y, en consecuencia, estas viviendas que ofrezcan estancias turísticas estén siempre supeditadas a la permisividad o no de estos instrumentos, sin que la no posibilidad de renovación pueda generar derechos, incluido el derecho a indemnizaciones». 
la STC de 22 de junio de 2017 al manifestar que la enumeración cerrada de las razones imperiosas del art. 3.11 de la Ley 17/2009 «es lo suficientemente abierta en sus términos como para que quepan dentro de aquella los diferentes objetivos que se pueden querer promover a través del amplio elenco de competencias autonómicas", objetivos que, en el caso concreto de las Islas Baleares, quedan reflejados en la exposición de motivos de la Ley 6/2017, de comercialización de estancias turísticas en viviendas, como acaba de subrayarse en las notas a pie.

En relación a todo lo que acaba de exponerse, cabe destacar que ya ha habido algunos pronunciamientos judiciales de diverso sentido. Así, la Sentencia 292/2016, de 31 de mayo, del Tribunal Superior de Justicia de Madrid, ha declarado nula la prohibición de que las viviendas de uso turístico se puedan alquilar menos de cinco días, prevista en el Decreto 79/2014, de 10 de julio, por el que se regulan los apartamentos turísticos y las viviendas de uso turístico en la Comunidad de Madrid. La razón sobre la que el Tribunal fundamenta su decisión es que se trata de una limitación temporal que no se justifica en una razón imperiosa de interés general, ya que no se motiva que sirva ni para evitar la opacidad fiscal ni para la protección de los usuarios (como se manifiesta en la exposición de motivos del Decreto 79/2014), y tampoco se prueba su proporcionalidad. Se trata de una medida restrictiva que favorece a los hoteleros, ya que normalmente el alquiler turístico se realiza por periodos muy cortos (no supera los cinco días) y que, por lo tanto, supone un obstáculo al mantenimiento de la competencia. Por el contrario, la citada sentencia considera que tanto la exigencia del plano de la vivienda visado por el colegio profesional competente como la inscripción en el registro para la publicidad oficial de la actividad son medidas ajustadas a derecho.

En un sentido semejante, basado en el tema del mantenimiento de la competencia, se ha manifestado también la Sentencia 41/2017, de 11 de marzo, del Tribunal Superior de Justicia de Canarias, que ha declarado nulo el precepto del Decreto 113/2015, de 22 de mayo, regulador del alquiler vacacional, que excluye del ámbito de aplicación del mismo las viviendas ubicadas en urbanizaciones turísticas o residenciales-turísticas. Al no preverse ninguna regulación acerca de las cuestiones relativas al alquiler que pueda darse en las zonas turísticas, el Tribunal Superior de Justicia ha considerado que la exclusión que realiza el Decreto del ámbito de aplicación es contraria a la libre competencia y es una manera de favorecer la industria turística tradicional. Destaca también el pronunciamiento sobre la declaración responsable y exigencia de registro, pues si bien declara ajustado a derecho la exigencia de declaración responsable para el inicio de la actividad, declara nulo el requerimiento de registro posterior, por tratarse, según el Tribunal, 
de un "control previo encubierto» ${ }^{50}$. Además, también declara nulo el precepto del Decreto que impide alquilar habitaciones. En la misma sentencia, sin embargo, se considera conforme a la legalidad la exigencia de estándares de calidad de las viviendas, de placa distintiva así como las cuestiones relativas a la información y publicidad o las condiciones de habitabilidad. Recientemente, en un Auto de fecha de 21 de diciembre de 2017, la Sección Primera de la Sala de lo Contencioso-Administrativo del Tribunal Supremo ha admitido a trámite el recurso de casación presentado por la Comunidad Autónoma de Canarias contra dicha Sentencia 41/2017. El Tribunal Supremo argumenta que hay «interés casacional» para revisar la Sentencia del Tribunal Superior de Justicia de Canarias, y que estudiará los argumentos planteados por la Comunidad Autónoma, que defiende el «interés general» en la negativa a abrir el alquiler vacacional en áreas turísticas y que la LAU impide alquilar habitaciones. Es decir, el Tribunal Supremo determinará si la regulación prevista en el Decreto 113/2015 que pretende limitar la oferta turística de viviendas y que exige que las viviendas vacacionales sean cedidas en su totalidad al cliente es o no contraria a lo establecido por el art. 5 de la Ley 20/2013, de garantía de la unidad de mercado, y si resulta proporcionada y está suficientemente justificada su necesidad por la salvaguarda de alguna razón imperiosa de interés general de entre las comprendidas en el art. 3.11 de la Ley 17/2009; además, el Tribunal Supremo también determinará la eventual contradicción de la previsión del decreto que impide alquilar habitaciones con lo dispuesto en el art. 5.e) de la LAU, que exige el cese de su totalidad.

No puede dejar de mencionarse, finalmente, la Sentencia de 15 de noviembre de 2017 del Tribunal Superior de Justicia de Galicia, que enjuicia el Decreto 12/2017, de 26 de enero, que regula la ordenación de los apartamentos turísticos, viviendas turísticas y viviendas de uso turístico. Este pronunciamiento judicial es favorable al contenido del Decreto, cuyas medidas limitativas (como, por ejemplo, la restricción del número máximo de viviendas) se consideran conformes a la libertad de empresa y la libre competencia, por estar justificadas en la necesidad de limitar las molestias a los residentes. En este caso, según el Tribunal, los límites impuestos se establecen en base a

50 Sobre la existencia de un posible control previo encubierto en el tándem regulador formado por la declaración responsable y el registro, véase Rodríguez Font (2017: 427-428). Aquí la autora analiza el Estudio sobre los nuevos modelos de prestación de servicios y la economía colaborativa, de marzo de 2016 (resultados preliminares E/ CNMV/004/15). La Comisión Nacional de los Mercados y Valores considera en este informe que el tándem regulador es un sistema de autorización encubierta incompatible con la Directiva de Servicios y la normativa de transposición. 
la competencia sobre urbanismo y convivencia y se enmarcan en la protección de un interés general que prevalece, que es el descanso de los vecinos; de modo que, dice la Sentencia, tanto la ordenación de los usos del sector como la comunidad de propietarios (propiedad horizontal) pueden establecer restricciones y prohibiciones. 